\title{
Stability of Dimethylmercury and Related Mercury-containing Compounds with Respect to Selected Chemical Species Found in Aqueous Environment ${ }^{\dagger}$
}

\author{
Laimutis Bytautas
}

\author{
Department of Chemistry, Rice University, Houston, Texas 77005, USA, \\ Present address: Galveston College, Department of Chemistry, 4015 Avenue Q, Galveston, TX, 77550, USA. \\ (E-mail: bytautas777@gmail.com)
}

RECEIVED JUNE 23, 2013; REVISED OCTOBER 3, 2013; ACCEPTED OCTOBER 4, 2013

\begin{abstract}
Dimethylmercury $\left(\mathrm{CH}_{3}-\mathrm{Hg}-\mathrm{CH}_{3}\right)$ and other $\mathrm{Hg}$-containing compounds can be found in atmospheric and aqueous environments. These substances are highly toxic and pose a serious environmental and health hazard. Therefore, the understanding of chemical processes that affect the stability of these substances is of great interest. The mercury-containing compounds can be detected in atmosphere, as well as soil and aqueous environments where, in addition to water molecules, numerous ionic species are abundant. In this study we explore the stability of several small, $\mathrm{Hg}$-containing compounds with respect to water molecules, hydronium $\left(\mathrm{H}_{3} \mathrm{O}^{+}\right)$ions as well as other small molecules/ions using density functional theory and wave function quantum chemistry methods. It is found that the stability of such molecules, most notably of dimethylmercury, can be strongly affected by the presence of the hydronium $\mathrm{H}_{3} \mathrm{O}^{+}$ions. Although the present theoretical study represents gas phase results, it implies that $\mathrm{pH}$ level of a solution should be a major factor in determining the degree of abundance for dimethylmercury in aqueous environment. In particular, it is found that $\mathrm{CH}_{3}-\mathrm{Hg}-\mathrm{CH}_{3}$ reacts readily with the $\mathrm{H}_{3} \mathrm{O}^{+}$ion producing $\mathrm{CH}_{3}-\mathrm{Hg}-\mathrm{OH}_{2}^{+}$and methane indicating that low-pH levels favor the decomposition of dimethylmercury. On the other hand, our study suggests that high-pH levels in aqueous environment would favor stronglybound complexes of $\left[\mathrm{CH}_{3}-\mathrm{Hg}-\mathrm{CH}_{3} \bullet \mathrm{OH}\right]^{-}$species. Overall, the theoretical evidence presented in this study offers an explanation for the available experimental data concerning the stability of dimethylmercury and other mercury-containing compounds having the general structure $\mathrm{X}-\mathrm{Hg}-\mathrm{Y}(\mathrm{X}, \mathrm{Y}=$ $\mathrm{CH}_{3}$ and $\mathrm{Cl}$ ) with respect to various ligands $\mathrm{L}\left(\mathrm{L}=\mathrm{H}_{2} \mathrm{O}, \mathrm{NH}_{3}, \mathrm{H}_{3} \mathrm{O}^{+}, \mathrm{OH}^{-}, \mathrm{Cl}^{-}\right.$and $\left.\mathrm{NH}_{4}^{+}\right)$. (doi: $10.5562 / \mathrm{cca} 2314)$
\end{abstract}

Keywords: dimethylmercury, ab initio quantum chemistry, potential energy surfaces, toxicology, mercury-containing compounds

\section{INTRODUCTION}

Elemental mercury $(\mathrm{Hg})$ is the only metal that is liquid at room temperature. This unique property evidently is related to relativistic effects. ${ }^{1,2}$ Over many years mercury has been classified as a transition element (see e.g. Ref. 3), however recently this classification has been challenged. A recent paper by Jensen ${ }^{4}$ suggests that $\mathrm{Hg}$ as well as $\mathrm{Zn}$ and $\mathrm{Cd}$ should not be classified as transition elements although some controversy still exists regarding this issue., ${ }^{5,6}$ The ground state electronic configuration of mercury atom is $[\mathrm{Xe}] 4 \mathrm{f}^{14} 5 \mathrm{~d}^{10} 6 \mathrm{~s}^{2}$ indicating that the $\mathrm{Hg}$-dimer should be a weakly bound van der Waals-type system in its ground state. ${ }^{7}$

Much attention has been dedicated to mercurycontaining compounds containing halogens and methyl groups that are of practical significance to the human population. A large body of experimental data documenting effects of mercury to human health has accumulated over many years. ${ }^{8-12}$ In this context, theoretical studies are important in elucidating possible chemical mechanisms involving Hg-containing species. ${ }^{13}$ It is well known that mercury and its compounds, especially methylmercury species, i.e. compounds containing $\mathrm{CH}_{3} \mathrm{Hg}$-group, are extremely toxic to humans and other living organisms. ${ }^{8-16}$ These compounds exist naturally in the environment, although human-related activities have contributed to the increased concentrations of mercury. It is understood that high affinity of the organomercurial compounds for thiols and lipophilic characteristics are the critical factors in their toxicity and various living organisms have developed unique neutralization mechanisms that counteract its effects. For example, bacteria developed two resistance pathways which involve the cleavage

\footnotetext{
$\dagger$ Dedicated to Professor Douglas Jay Klein on the occasion of his $70^{\text {th }}$ birthday.
} 
of $\mathrm{Hg}-\mathrm{C}$ bond with a subsequent reduction of the mercuric residues to elemental mercury. ${ }^{15,16}$ The presence of methylmercurials in soil, aqueous environment and the atmosphere is well documented. ${ }^{17-27}$ Due to various transport mechanisms such compounds accumulate in living organisms, especially in aquatic environments. Methylmercury species are known ${ }^{8}$ to cross the bloodbrain barrier and are highly neurotoxic. One of the most toxic forms to humans among many mercury-containing chemical compounds is dimethylmercury (DMHg) with its chemical formula $\mathrm{CH}_{3}-\mathrm{Hg}-\mathrm{CH}_{3}$. DMHg is a nonpolar compound and readily accumulates in fatty tissues. ${ }^{8,14}$ One of the important aspects in reducing the long-term exposure of methylmecury compounds to human population relates to understanding of chemical and physical processes controlling its concentration. Therefore, a significant volume of research has been dedicated to methylmercury, its demethylation as well as exploring other possible mechanisms involving mercury. $^{28-34}$ Evidently, DMHg is the predominant methylated form of mercury in the deep ocean. ${ }^{23}$ It has been suggest$\mathrm{ed}^{24}$ that the oceanic DMHg is the main source of monomethylmercury (MMHg) in the water column. The $\mathrm{MMHg}$ compound (i.e. methylmercury monocation $\left[\mathrm{CH}_{3}-\mathrm{Hg}\right]^{+}$) plays a significant role in the aqueous environment due to its ability to biomagnify in aquatic food chains leading to high toxicity levels in fish and other organisms. This seems to be the main pathway to the exposure of mercury to human population. ${ }^{8,12}$ Recent findings of Conaway et $\mathrm{al}^{22}$ indicate unexpectedly high concentrations of DMHg in costal surface waters. Some studies $^{35}$ suggest that one possible route for the degradation of DMHg into MMHg in aqueous environments is by evaporating of $\mathrm{DMHg}$ into the atmosphere and, after the chemical transformation into $\mathrm{MMHg}$, being brought back to the Ocean waters by aerosols or water vapor. An alternative route for the transformation from $\mathrm{DMHg}$ to MMHg may involve mechanisms and chemical species that can occur directly in aqueous environments.

A number of theoretical studies investigating chemistry of mercury-containing compounds have already been reported in the literature. ${ }^{36-44}$ For example, mechanisms associated with the $\mathrm{Hg}-\mathrm{C}$ bond cleavage by halogenic acids have been investigated by Barone and co-workers. ${ }^{15} \mathrm{Ni}$ et $a .^{36}$ investigated possible mechanisms for degrading chloromethylmercury $\left(\mathrm{CH}_{3}-\mathrm{Hg}-\mathrm{Cl}\right)$ and dimethylmercury $\left(\mathrm{CH}_{3}-\mathrm{Hg}-\mathrm{CH}_{3}\right)$ involving thiol and ammonium residues. Khalizov et $a l .{ }^{37}$ studied the reactions of $\mathrm{Hg}$ with halogens and discussed their atmospheric implications. Shepler et al. ${ }^{38}$ have analyzed the effects of aqueous solvation on the thermochemistry of reactions between $\mathrm{Hg}$ and small halogen molecules. Furthermore, it has been proposed that organic mercury-containing compounds can be broken-down into less toxic species via photo-reduction and microbe-assisted transformations. ${ }^{44,45}$ The role played by humic acids that are abundant in aqueous environment has been recently discussed in Ref. 20. A study by Tossell ${ }^{44}$ examined the reaction energies for the formation of various $\mathrm{CH}_{3}-\mathrm{Hg}-\mathrm{L}$ species resulting from $\mathrm{CH}_{3}-\mathrm{Hg}^{+}$and ligands $\mathrm{L}$. In particular, Tossell's study ${ }^{44}$ indicates that $\left(\mathrm{CH}_{3}-\mathrm{Hg}-\mathrm{OH}_{2}{ }^{+}\right)$should be the most dominant species in natural water systems.

Since methylmercury species frequently occur in aquatic environments, one of important questions is investigating the stability of these compounds with respect to exposure of water molecules as well as hydronium $\left(\mathrm{H}_{3} \mathrm{O}^{+}\right)$and hydroxide $\left(\mathrm{OH}^{-}\right)$ions which, in turn are associated with $\mathrm{pH}$ levels of aqueous environments. Of particular interest is the observed correlation between low $\mathrm{pH}$ levels and instability of $\mathrm{DMHg} .^{32-34}$ Thus, the goal of the present theoretical study is to explore possible mechanisms that can contribute to the chemical degradation of DMHg $\left(\mathrm{CH}_{3}-\mathrm{Hg}-\mathrm{CH}_{3}\right)$.

\section{METHODOLOGY AND TECHNICAL DETAILS}

The geometry optimizations in this study were performed for the following systems: $\mathrm{H}_{2} \mathrm{O}, \mathrm{H}_{3} \mathrm{O}^{+}, \mathrm{OH}^{-}, \mathrm{Cl}^{-}, \mathrm{NH}_{4}^{+}$, $\mathrm{CH}_{3}-\mathrm{Hg}-\mathrm{CH}_{3}, \mathrm{CH}_{3}-\mathrm{Hg}-\mathrm{Cl}, \mathrm{Cl}-\mathrm{Hg}-\mathrm{Cl}, \mathrm{CH}_{3}-\mathrm{Hg}-\mathrm{OH}_{2}{ }^{+}$. The ability of the $\mathrm{Hg}$-containing compounds, i.e. $\mathrm{CH}_{3}-\mathrm{Hg}-\mathrm{CH}_{3}, \mathrm{CH}_{3}-\mathrm{Hg}-\mathrm{Cl}$ and $\mathrm{Cl}-\mathrm{Hg}-\mathrm{Cl}$ to form complexes with the molecules of $\mathrm{H}_{2} \mathrm{O}, \mathrm{H}_{3} \mathrm{O}^{+}, \mathrm{OH}^{-}, \mathrm{Cl}^{-}$, $\mathrm{NH}_{4}^{+}$is explored by optimizing the geometries with the inclusion of the counterpoise correction (CP) to correct for the basis-set-superposition-error (BSSE). ${ }^{46}$ The basis set used in all the calculations is $6-31 \mathrm{G}(\mathrm{d}, \mathrm{p}$ ) (spherical harmonics) for all atoms except mercury. For the $\mathrm{Hg}$ atom the Stuttgart/Dresden pseudo-potential (effectivecore-potential) MDF60 (see Refs. 47,48) was used to treat core electrons while the MWB60 basis set was used to treat valence electrons. The initial optimization step uses PBE DFT-functional and the resulting optimized geometry is used as the starting point in the MP2 optimization. After the geometry is optimized at the MP2 level of theory, a single-point $\operatorname{CCSD}(\mathrm{T})$ calculation is performed to obtain the total energy (electronic energy including nuclear repulsion). The vibrational analysis and the zero-point-energies correspond to the MP2 level of theory. All calculations were performed using GAUSSIAN package of $a b$ initio programs. ${ }^{49}$ Only local minima on the singlet ground-state potential energy surface ${ }^{50-52}$ have been considered in this study.

\section{RESULTS AND DISCUSSION}

The strategy of this investigation is to explore possible complexes of the $\mathrm{Hg}$-containing compounds, namely $\mathrm{CH}_{3}-\mathrm{Hg}-\mathrm{CH}_{3}, \mathrm{CH}_{3}-\mathrm{Hg}-\mathrm{Cl}$ and $\mathrm{Cl}-\mathrm{Hg}-\mathrm{Cl}$, with small 
ligand molecules of $\mathrm{H}_{2} \mathrm{O}, \mathrm{NH}_{3}, \mathrm{CH}_{4}$ (neutral species) as well as ions of $\mathrm{H}_{3} \mathrm{O}^{+}, \mathrm{OH}^{-}, \mathrm{Cl}^{-}, \mathrm{NH}_{4}{ }^{+}$. As a first step, we calibrate our methods and basis sets against the benchmark data found in literature for selected molecular species to make sure that they are appropriate for the present investigation. We note that the goal of the calibration step is not the quest for an extraordinary high accuracy (our chosen basis sets are too small for this purpose) but rather to show that our final conclusions are expected to be reliable regarding the energetics of dissociation pathways of the $\mathrm{Hg}$-containing compounds. We select $\mathrm{Cl}-\mathrm{Hg}-\mathrm{Cl}$ as our first case and compare our MP2 optimized geometry and vibrational frequencies with the previous high level calculations and experimental data. ${ }^{53-55}$ The results are displayed in Table 1. As can be seen from the table the results of our MP2 optimization while not perfect yield quite satisfactory results. We also provide a comparison with experiment ${ }^{56}$ of our MP2 optimized geometry for the $\mathrm{CH}_{3}-\mathrm{Hg}-\mathrm{Cl}$ compound in the supplementary material (see Table S1). The evidence supports that our level of theory and basis sets are capable of providing reliable results. To estimate the quality of our methodology on a weakly-bound neutral system we select the water dimer ${ }^{57}$ as an example. We also consider the $\mathrm{H}_{5} \mathrm{O}_{2}^{+}$molecule ${ }^{58-61}$ as an example of a strongly-bound ionic system resulting from the interaction between the hydronium ion and water. We perform MP2 geometry optimizations for the water dimer and the $\mathrm{H}_{5} \mathrm{O}_{2}{ }^{+}$compound. Then, we calculate their dissociation energies (including the $\mathrm{CP}$ correction for BSSE) as described below. For the water dimer, the dissociation process is: $\left(\mathrm{H}_{2} \mathrm{O} \cdot \mathrm{H}_{2} \mathrm{O}\right) \rightarrow \mathrm{H}_{2} \mathrm{O}+\mathrm{H}_{2} \mathrm{O}$. For $\mathrm{H}_{5} \mathrm{O}_{2}^{+}$, the dissociation process is: $\mathrm{H}_{5} \mathrm{O}_{2}^{+} \rightarrow \mathrm{H}_{2} \mathrm{O}+$ $\mathrm{H}_{3} \mathrm{O}^{+}$. Of course, the calculation of these dissociation energies requires also MP2-geometry optimizations for $\mathrm{H}_{2} \mathrm{O}$ and $\mathrm{H}_{3} \mathrm{O}^{+}$structures. As seen in Table $\mathrm{S} 1$ of the supplementary material, our $[\mathrm{MP} 2 / 6-31 \mathrm{G}(\mathrm{d}, \mathrm{p})]$ value for the water-dimer dissociation energy of $\mathrm{D}_{0}=2.6$ $\mathrm{kcal} / \mathrm{mol}$ compares very well with the benchmark value of $2.88 \mathrm{kcal} / \mathrm{mol}$ of Ref. 57 . The optimized geometries for the water dimer and $\mathrm{H}_{5} \mathrm{O}_{2}{ }^{+}$are displayed in Figure $\mathrm{S} 1$ (Figure S1A represents the water dimer geometry and Figure $\mathrm{S} 1 \mathrm{~B}$ represents that for the $\mathrm{H}_{5} \mathrm{O}_{2}{ }^{+}$molecule). For the $\mathrm{H}_{5} \mathrm{O}_{2}{ }^{+}$molecule, the data is displayed in Table $\mathrm{S} 2$ of the supplementary material. The geometry optimizations for $\mathrm{H}_{5} \mathrm{O}_{2}{ }^{+}$(with the counterpoise $(\mathrm{CP})$ correction), $\mathrm{H}_{3} \mathrm{O}^{+}$(without $\mathrm{CP}$ correction) and $\mathrm{H}_{2} \mathrm{O}$ (without $\mathrm{CP}$ correction) have been performed at MP2 level of theory using $6-31 \mathrm{G}(\mathrm{d}, \mathrm{p})$ basis set. The total electronic energies from MP2 and $\operatorname{CCSD}(\mathrm{T})$ calculations are reported in Table S2 of the supplementary material for each molecule (in hartree). The $\operatorname{CCSD}(\mathrm{T})$ energies have been calculated at the MP2-optimized geometries. Regarding the dissociation energy value $\mathrm{D}_{\mathrm{e}}$, it is evident that an agreement of the $\operatorname{CCSD}(\mathrm{T})$ result with the recent benchmark of Ref. 61 is excellent, the discrepancy being only $1.1 \mathrm{kcal} / \mathrm{mol}$. The numerical data above clearly indicate that our selected theoretical methods and basis sets yield good-quality structures for neutral as well as charged molecular species that are relevant to the present study. Thus, it is expected that the following energies based on MP2-optimized geometries and $\operatorname{CCSD}(\mathrm{T})$ single-point energy calculations are reliable. Table S2 (see supplementary material) also lists the effect of zero-point-energies (ZPE) on the dissociation energy for the MP2 value (in parentheses). Next, we shall calculate the dissociation energies (without and with inclusion of ZPE) for bound complexes that involve neutral compounds $\mathrm{CH}_{3}-\mathrm{Hg}-\mathrm{CH}_{3}, \mathrm{CH}_{3}-\mathrm{Hg}-\mathrm{Cl}$ and $\mathrm{Cl}-\mathrm{Hg}-\mathrm{Cl}$ with neutral species (ligands) of $\mathrm{H}_{2} \mathrm{O}, \mathrm{NH}_{3}$ and $\mathrm{CH}_{4}$ and examine their stability. Then, we obtain the binding energies of neutral compounds $\mathrm{CH}_{3}-\mathrm{Hg}-\mathrm{CH}_{3}$, $\mathrm{CH}_{3}-\mathrm{Hg}-\mathrm{Cl}, \mathrm{Cl}-\mathrm{Hg}-\mathrm{Cl}$ with ionic species of $\mathrm{H}_{3} \mathrm{O}^{+}$, $\mathrm{OH}^{-}, \mathrm{Cl}^{-}$and $\mathrm{NH}_{4}^{+}$. Finally, we shall discuss the energetics and thermochemistry of these cases and draw our conclusions regarding the stability and most favorable decomposition pathways for the mercury-containing species, namely $\mathrm{CH}_{3}-\mathrm{Hg}-\mathrm{CH}_{3}, \quad \mathrm{CH}_{3}-\mathrm{Hg}-\mathrm{Cl}$ and $\mathrm{Cl}-\mathrm{Hg}-\mathrm{Cl}$ in aqueous environments.

\section{$\mathrm{X}-\mathrm{Hg}-\mathrm{Y}$ Interaction with Neutral Ligands $\mathrm{L}(\mathrm{L}=$ $\mathrm{H}_{2} \mathrm{O}$ and $\mathrm{NH}_{3}$ )}

The interaction and binding strength between $\mathrm{X}-\mathrm{Hg}-\mathrm{Y}$ and any of the neutral ligands $\mathrm{L}\left(\mathrm{L}=\mathrm{H}_{2} \mathrm{O}\right.$ or $\left.\mathrm{NH}_{3}\right)$ where each symbol, $\mathrm{X}$ and $\mathrm{Y}$, represents either $\mathrm{CH}_{3}$-group or $\mathrm{Cl}$-atom, has been calculated in an analogous manner as discussed above. The geometry of the $\mathrm{NH}_{3}$ molecule is displayed in Figure S2 (panel A) of the supplementary material. The total electronic energies are then used for calculating energy differences to obtain binding electronic energies $\Delta E$. In order to account for ZPE effects due to molecular vibrations, one must correct $\Delta E$ value by adding ZPE differences between reacting species, thus obtaining $(\Delta E+\Delta \mathrm{ZPE})$ value as $\mathrm{ZPE}$-adjusted binding energy. In our notation, $\Delta E=-D_{\mathrm{e}}$ and $\Delta E(\mathrm{ZPE})=$ $-D_{0}$.

The computational data documenting the interaction of $\mathrm{X}-\mathrm{Hg}-\mathrm{Y}$ species with neutral ligands $\mathrm{L}$ is listed in Table 2. The energetics for the complex formation as well as Gibbs free energy change and equilibrium constants are displayed in the table for $\mathrm{X}-\mathrm{Hg}-\mathrm{Y}$ complexes, namely $\mathrm{CH}_{3}-\mathrm{Hg}-\mathrm{CH}_{3}, \mathrm{CH}_{3}-\mathrm{Hg}-\mathrm{Cl}, \mathrm{Cl}-\mathrm{Hg}-\mathrm{Cl}$ that form with the $\mathrm{H}_{2} \mathrm{O}$ molecule (rows I to III) and $\left[\mathrm{CH}_{3}-\mathrm{Hg}-\mathrm{CH}_{3} \bullet \mathrm{NH}_{3}\right]$ (row IV). From Table 2 it is evident that the magnitude of binding energy, $\Delta E$ and $\triangle E(\mathrm{ZPE})$, steadily increases going from $\left[\mathrm{CH}_{3}-\mathrm{Hg}-\mathrm{CH}_{3} \bullet \mathrm{H}_{2} \mathrm{O}\right]$ to $\left[\mathrm{CH}_{3}-\mathrm{Hg}-\mathrm{Cl} \bullet \mathrm{H}_{2} \mathrm{O}\right]$ and to $\left[\mathrm{Cl}-\mathrm{Hg}-\mathrm{Cl} \bullet \mathrm{H}_{2} \mathrm{O}\right]$ as the total number of electronegative ligands $\mathrm{L}$ increases from $\left(\mathrm{L}=\right.$ two $\mathrm{CH}_{3}$ groups) to $(\mathrm{L}=$ one $\mathrm{CH}_{3}$ and $\mathrm{Cl}$ ) to $(\mathrm{L}=$ two $\mathrm{Cl}$ ligands), respectively. 

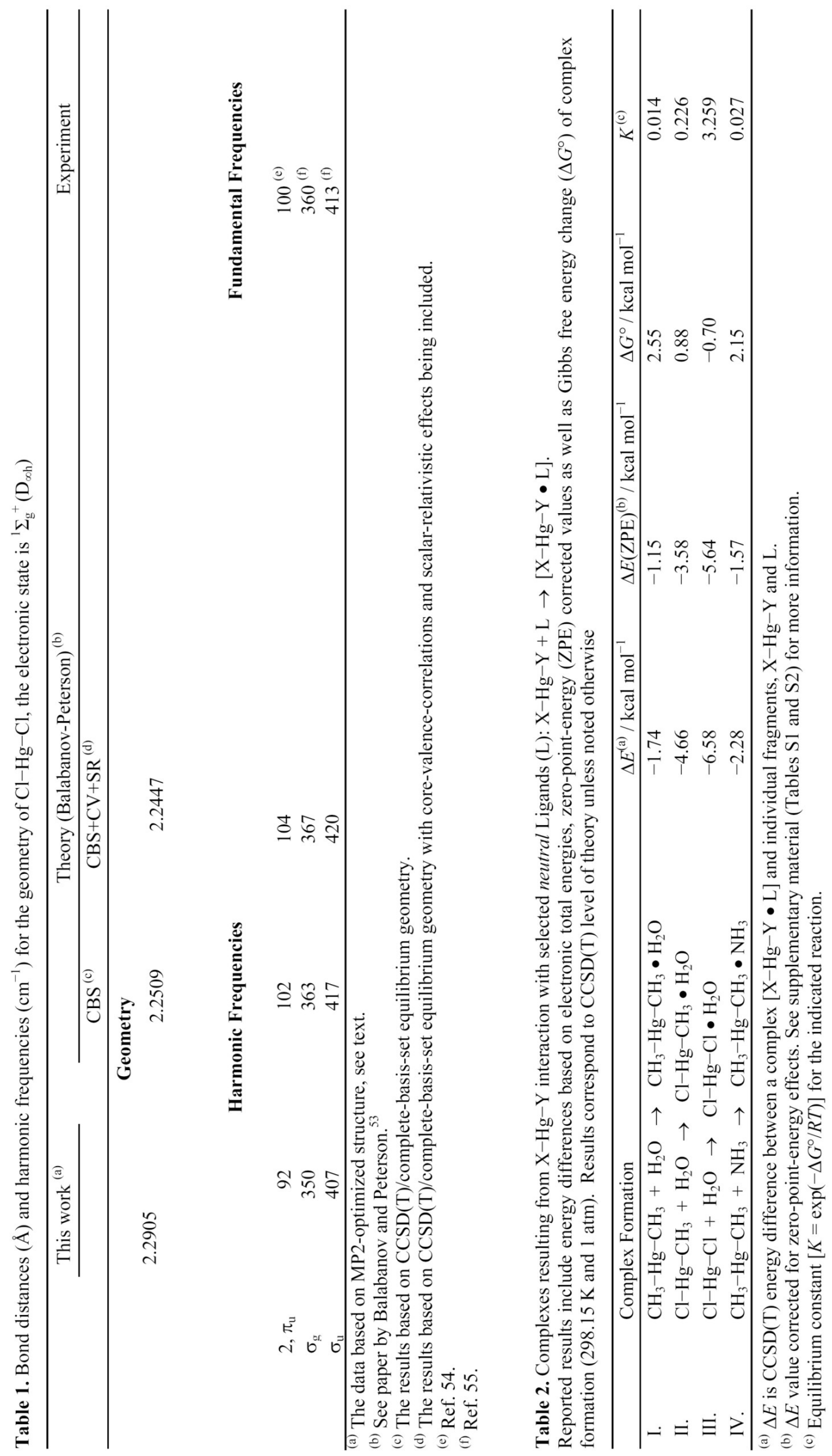

Croat. Chem. Acta 86 (2013) 453. 


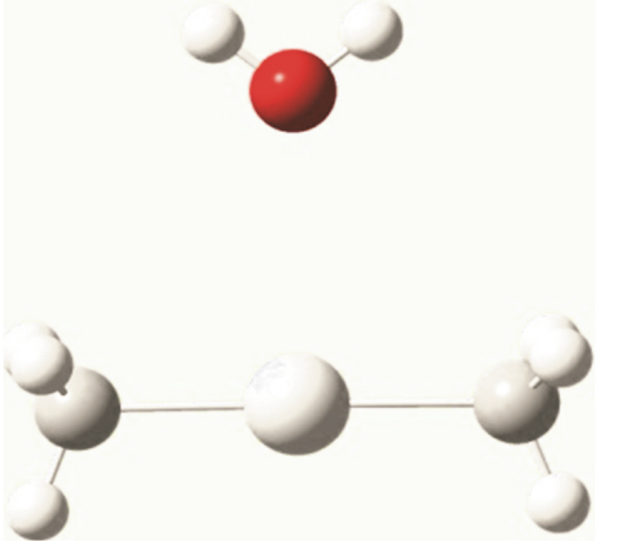

(A) $\mathrm{CH}_{3}-\mathrm{Hg}-\mathrm{CH}_{3} \bullet \mathrm{H}_{2} \mathrm{O}$

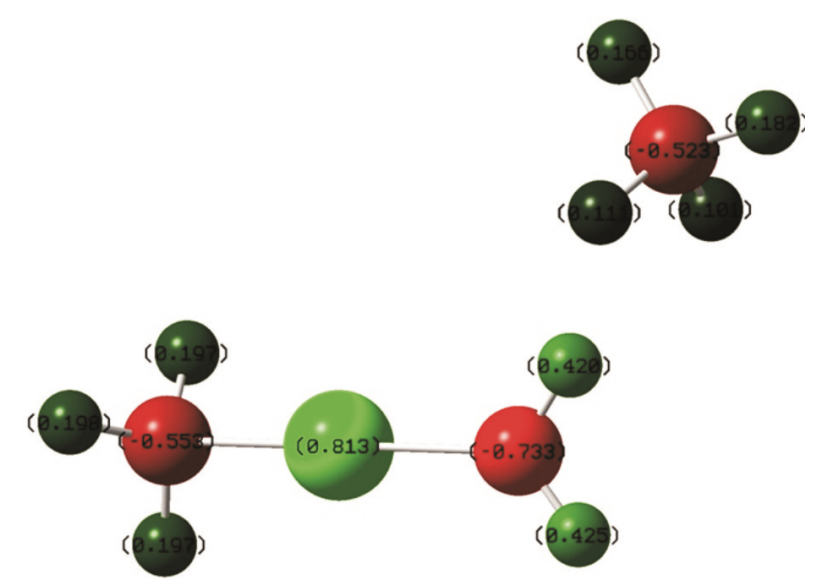

(B) PRODUCT FROM:

$\mathrm{CH}_{3}-\mathrm{Hg}-\mathrm{CH}_{3}+\mathrm{H}_{3} \mathrm{O}^{+} \rightarrow \quad\left[\mathrm{CH}_{3}-\mathrm{Hg}-\mathrm{OH}_{2}\right]^{+} \bullet \mathrm{CH}_{4}$

Figure 1. The bound complexes resulting from the interaction of $\mathrm{CH}_{3}-\mathrm{Hg}-\mathrm{CH}_{3}$ with $\mathrm{H}_{2} \mathrm{O}$ (panel A) and $\mathrm{H}_{3} \mathrm{O}^{+}$(panel B). In panel B the product of a barrier-less reaction: $\mathrm{CH}_{3}-\mathrm{Hg}-\mathrm{CH}_{3}+$ $\mathrm{H}_{3} \mathrm{O}^{+} \rightarrow\left[\mathrm{CH}_{3}-\mathrm{Hg}-\mathrm{OH}_{2} \bullet \mathrm{CH}_{4}\right]^{+}$is displayed.

It is to be expected that as the electron density from the central $\mathrm{Hg}$ atom in $\mathrm{X}-\mathrm{Hg}-\mathrm{Y}$ is withdrawn towards the electronegative ligand (chlorine) the binding of $\mathrm{H}_{2} \mathrm{O}$ to $\mathrm{X}-\mathrm{Hg}-\mathrm{Y}$ gets stronger. Figures 1,2 and 3 (panels A) clearly illustrate this trend. Finally, from Table 2 one can see that the binding energy for $\left[\mathrm{CH}_{3}-\mathrm{Hg}-\mathrm{CH}_{3} \bullet \mathrm{NH}_{3}\right]$ is slightly larger than that in $\left[\mathrm{CH}_{3}-\mathrm{Hg}-\mathrm{CH}_{3} \bullet \mathrm{H}_{2} \mathrm{O}\right]$ (see Figure 4, panel A) which could be rationalized on the basis of larger basicity of $\mathrm{NH}_{3}$ relative to $\mathrm{H}_{2} \mathrm{O}$.

$\mathrm{X}-\mathrm{Hg}-\mathrm{Y}$ interaction with ionic ligands $\mathrm{L}\left(\mathrm{L}=\mathrm{H}_{3} \mathrm{O}^{+}\right.$, $\mathrm{OH}^{-}, \mathrm{Cl}^{-}$and $\mathrm{NH}_{4}^{+}$)

Now, we shall examine the interaction and binding energy between $\mathrm{X}-\mathrm{Hg}-\mathrm{Y}$ and any of the ionic ligands $\mathrm{L}$ ( $\mathrm{L}=\mathrm{H}_{3} \mathrm{O}^{+}, \mathrm{OH}^{-}, \mathrm{Cl}^{-}$and $\mathrm{NH}_{4}^{+}$) where each symbol, $\mathrm{X}$ and $\mathrm{Y}$, represents either $\mathrm{CH}_{3}$-group or $\mathrm{Cl}$-atom. The

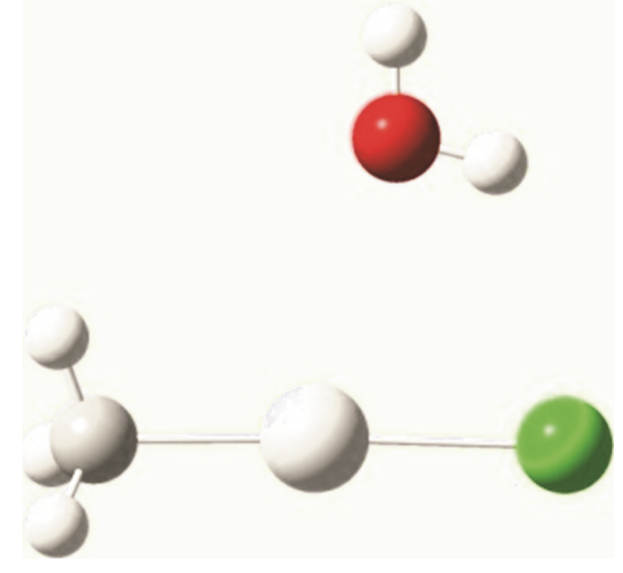

(A) $\mathrm{CH}_{3}-\mathrm{Hg}-\mathrm{Cl} \bullet \mathrm{H}_{2} \mathrm{O}$

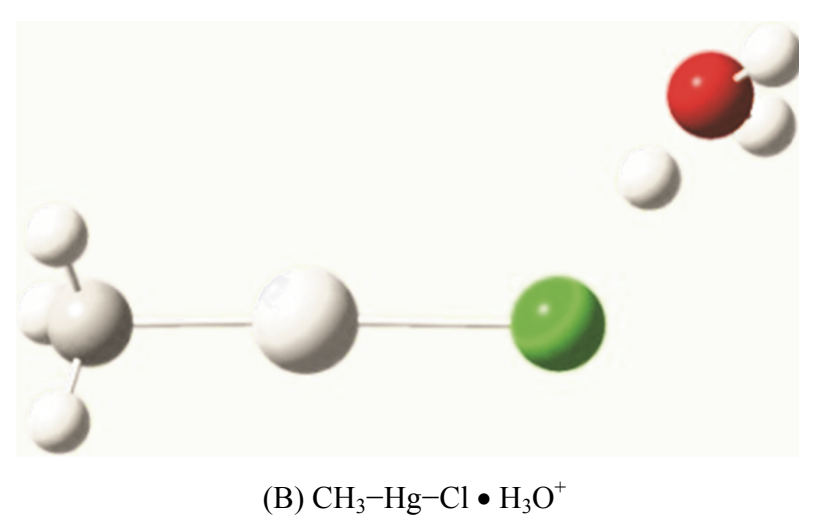

Figure 2. The bound complexes resulting from the interaction of $\mathrm{CH}_{3}-\mathrm{Hg}-\mathrm{Cl}$ with $\mathrm{H}_{2} \mathrm{O}$ (panel A) and $\mathrm{H}_{3} \mathrm{O}^{+}$(panel B).

calculations follow the same procedure as discussed in the preceding section. The optimized geometry for $\mathrm{NH}_{4}{ }^{+}$ is displayed in Figure S2 (panel B) of the supplementary material. The relevant data is displayed in Table 3. The display of the contents in these tables is analogous to that of Table 2. Table 3 lists the data of interaction of $\left(\mathrm{CH}_{3}-\mathrm{Hg}-\mathrm{CH}_{3}\right)$ with ions $\mathrm{H}_{3} \mathrm{O}^{+}, \mathrm{OH}^{-}, \mathrm{Cl}^{-}$and $\mathrm{NH}_{4}^{+}$. From this table it is evident that the binding energy for $\left[\mathrm{CH}_{3}-\mathrm{Hg}-\mathrm{CH}_{3} \bullet \mathrm{NH}_{4}\right]^{+}$(see Figure 4panel B), $\left[\mathrm{CH}_{3}-\mathrm{Hg}-\mathrm{CH}_{3} \bullet \mathrm{Cl}\right]^{-}$(see Figure 5) and $\left[\mathrm{CH}_{3}-\mathrm{Hg}-\mathrm{CH}_{3} \bullet \mathrm{OH}\right]^{-}$(see Figure 6) increases as the bound ligand $L$ changes from $\mathrm{NH}_{4}^{+}$to $\mathrm{Cl}^{-}$and then to $\mathrm{OH}^{-}$. Since the concentration of $\mathrm{OH}^{-}$ions in aqueous solution is a measure of $\mathrm{pOH}$ value, it is expected that basic solutions will favor the reduction of dimethylmercury concentration by producing strongly bound $\left[\mathrm{CH}_{3}-\mathrm{Hg}-\mathrm{CH}_{3} \bullet \mathrm{OH}\right]^{-}$.

Next, we examine the reaction of dimethylmercury with the hydronium ion. The relevant data is listed in the first row of Table 3. The MP2 optimization starting with $\left(\mathrm{CH}_{3}-\mathrm{Hg}-\mathrm{CH}_{3}\right)$ and $\mathrm{H}_{3} \mathrm{O}^{+}$molecules placed at a short distance apart (ranging from about $3 \AA$ to $6 \AA$ from the $\mathrm{Hg}$ atom to $\mathrm{H}_{3} \mathrm{O}^{+}$) indicates that the 


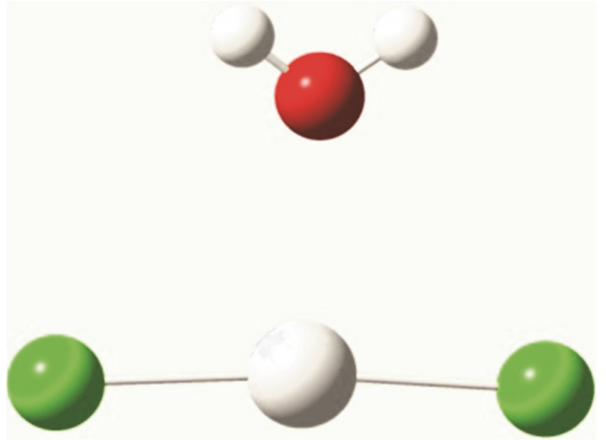

(A) $\mathrm{Cl}-\mathrm{Hg}-\mathrm{Cl} \bullet \mathrm{H}_{2} \mathrm{O}$

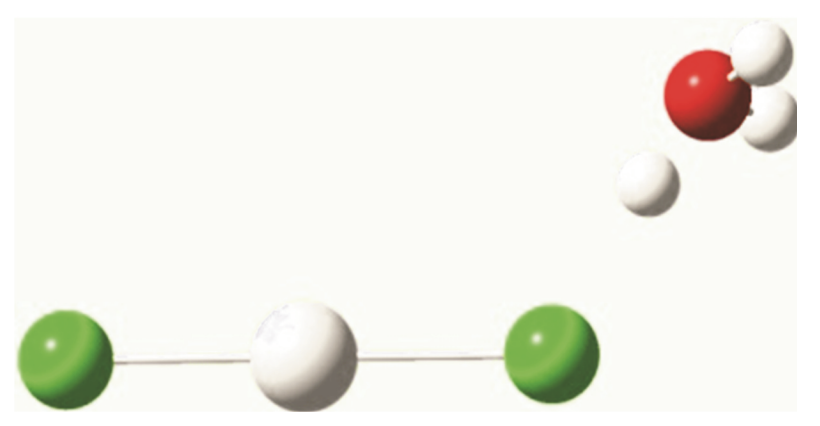

(B) $\mathrm{Cl}-\mathrm{Hg}-\mathrm{Cl} \bullet \mathrm{H}_{3} \mathrm{O}^{+}$

Figure 3. The bound complexes resulting from the interaction of $\mathrm{Cl}-\mathrm{Hg}-\mathrm{Cl}$ with $\mathrm{H}_{2} \mathrm{O}$ (panel A) and $\mathrm{H}_{3} \mathrm{O}^{+}$(panel B).

$\left[\mathrm{CH}_{3}-\mathrm{Hg}-\mathrm{CH}_{3} \bullet \mathrm{H}_{3} \mathrm{O}\right]^{+}$system decomposes readily without a barrier into $\left[\mathrm{CH}_{3}-\mathrm{Hg}-\mathrm{OH}_{2}\right]^{+}$and methane (see Figure 1, panel B). This result can be easily understood if we consider various decomposition fragments of the combined system, i.e. $\mathrm{CH}_{3}-\mathrm{Hg}-\mathrm{CH}_{3}$ and $\mathrm{H}_{3} \mathrm{O}^{+}$. In Table 4 such different fragments are labeled as System-I, System-II and System-III. It is clearly evident that the System-III containing $\left[\mathrm{CH}_{3}-\mathrm{Hg}-\mathrm{OH}_{2}\right]^{+}$and methane $\left(\mathrm{CH}_{4}\right)$ as sum of two individual (noninteracting) fragments is by far the most stable, i.e. has the lowest electronic energy among them. Furthermore, there seems to be no barrier that could prevent the original system, i.e. $\left[\mathrm{CH}_{3}-\mathrm{Hg}-\mathrm{CH}_{3}\right]$ plus $\mathrm{H}_{3} \mathrm{O}^{+}$, from ending up in this potential energy minimum. It may be noted that the absence of the energy barrier does not negate the existence of a transition state which can be determined on the basis of other considerations, e.g., minimum flux using variational transition state theory ${ }^{62,63}$ (see also Refs. 64,65). As a follow up investigation we performed an MP2 optimization for a weakly-bound complex $\left[\mathrm{CH}_{3}-\mathrm{Hg}-\mathrm{OH}_{2} \bullet \mathrm{CH}_{4}\right]^{+}$which is labeled as System-IV in Table 4. It is found that this complex has nearly negligible binding energy of only $1.4 \mathrm{kcal} / \mathrm{mol}$. The geometry of this complex is displayed in Figure 1 (panel B) where the Mulliken charges are also listed. The large positive charge exhibited by the mercury atom
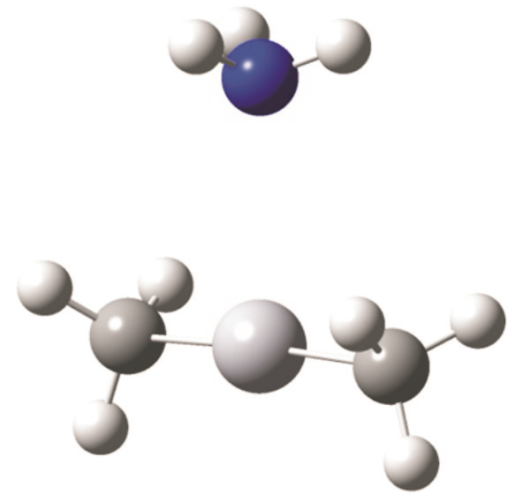

(A) $\mathrm{CH}_{3}-\mathrm{Hg}-\mathrm{CH}_{3} \bullet \mathrm{NH}_{3}$
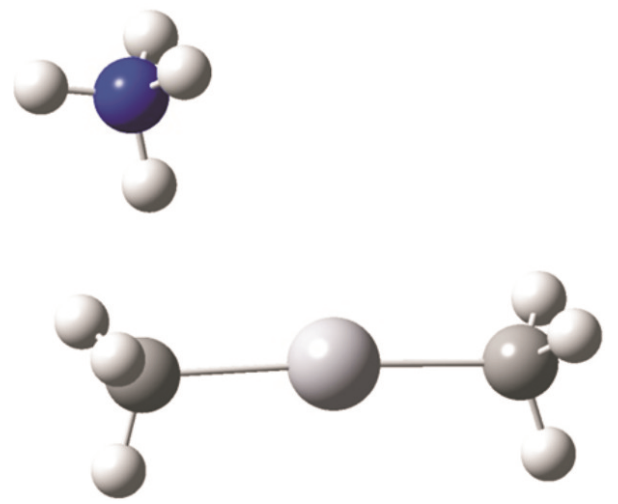

(B) $\left[\mathrm{CH}_{3}-\mathrm{Hg}-\mathrm{CH}_{3} \bullet \mathrm{NH}_{4}\right]^{+}$

Figure 4. The bound complexes resulting from the interaction of $\mathrm{CH}_{3}-\mathrm{Hg}-\mathrm{CH}_{3}$ with $\mathrm{NH}_{3}$ (panel A) and $\mathrm{NH}_{4}{ }^{+}$(panel B).

is indicative of its cationic character that is commonly found in $\mathrm{X}-\mathrm{Hg}-\mathrm{Y}$ structures including some stable biomolecular complexes like $\mathrm{T}-\mathrm{Hg}-\mathrm{T}^{66}$ where $\mathrm{T}=$ thymine.

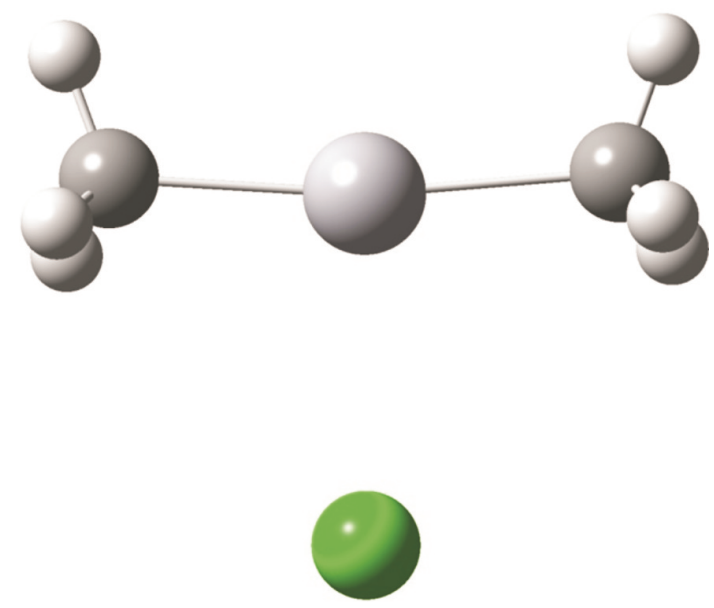

Figure 5. Optimized geometry for the $\left[\mathrm{CH}_{3}-\mathrm{Hg}-\mathrm{CH}_{3} \bullet \mathrm{Cl}\right]$ ionic complex. 

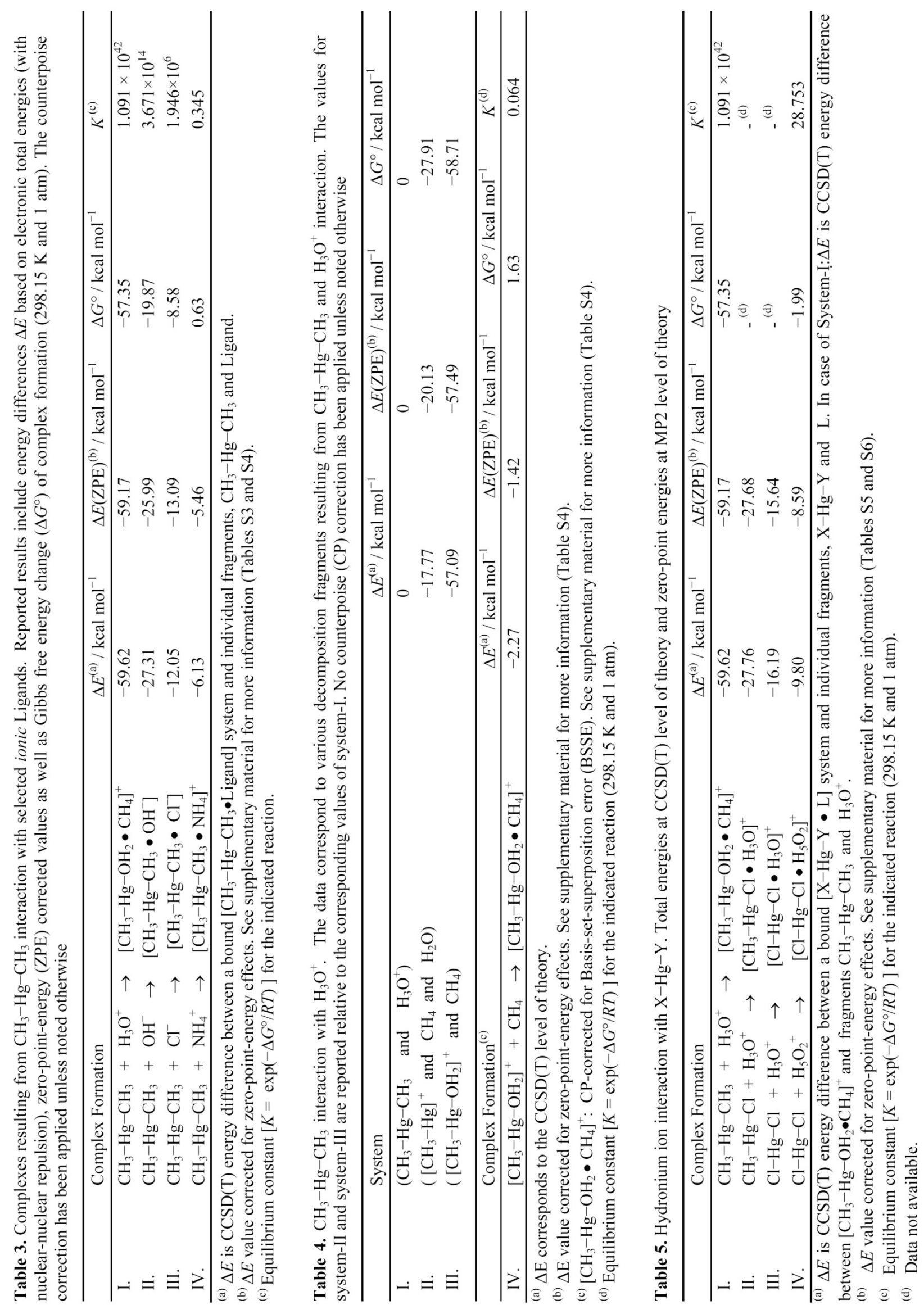


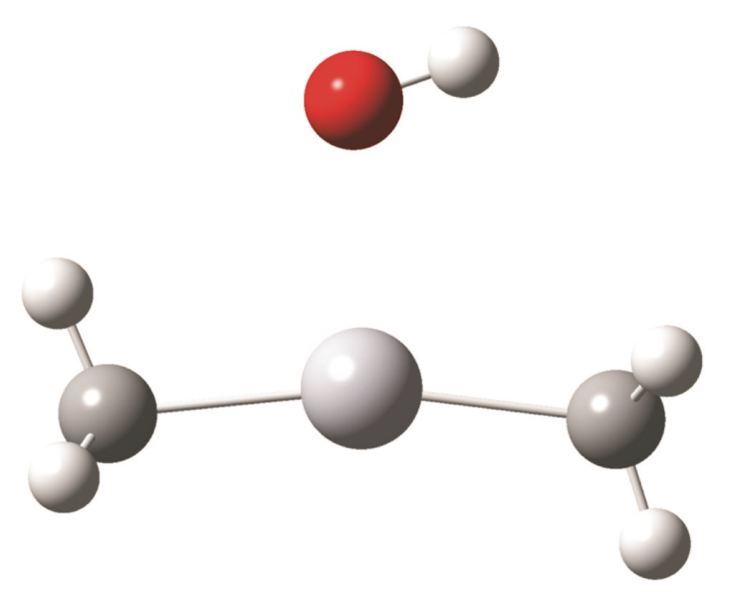

Figure 6. Optimized geometry for the $\left[\mathrm{CH}_{3}-\mathrm{Hg}-\mathrm{CH}_{3} \bullet \mathrm{OH}\right]$ ionic complex.

Finally, in Table 5 we compare binding energies of the hydronium ion with all three $\mathrm{X}-\mathrm{Hg}-\mathrm{Y}$ structures, namely $\left[\mathrm{CH}_{3}-\mathrm{Hg}-\mathrm{CH}_{3}\right.$ plus $\left.\mathrm{H}_{3} \mathrm{O}^{+}\right],\left[\mathrm{CH}_{3}-\mathrm{Hg}-\mathrm{Cl}\right.$ plus $\left.\mathrm{H}_{3} \mathrm{O}^{+}\right]$and $\left[\mathrm{Cl}-\mathrm{Hg}-\mathrm{Cl}\right.$ plus $\left.\mathrm{H}_{3} \mathrm{O}^{+}\right]$that are labeled as System-I, System-II and System-III, respectively. From Table 5 it is evident that the binding energy increases going from $\left[\mathrm{Cl}-\mathrm{Hg}-\mathrm{Cl} \bullet \mathrm{H}_{3} \mathrm{O}^{+}\right.$(see Figure 3-panel B) to $\left[\mathrm{CH}_{3}-\mathrm{Hg}-\mathrm{Cl} \bullet \mathrm{H}_{3} \mathrm{O}^{+}\right]$(see Figure 2-panel $\mathrm{B}$ ) and to $\left[\mathrm{CH}_{3}-\mathrm{Hg}-\mathrm{CH}_{3}\right.$ plus $\left.\mathrm{H}_{3} \mathrm{O}^{+}\right]$(see Figure 1-panel B). The reaction of $\mathrm{CH}_{3}-\mathrm{Hg}-\mathrm{CH}_{3}$ with $\mathrm{H}_{3} \mathrm{O}^{+}$produces a much more stable complex $\left[\mathrm{CH}_{3}-\mathrm{Hg}-\mathrm{OH}_{2} \bullet \mathrm{CH}_{4}\right]^{+}$. This trend in binding energies is also displayed graphically in Figure 7. While the reaction $\mathrm{CH}_{3}-\mathrm{Hg}-\mathrm{CH}_{3}+\mathrm{H}_{3} \mathrm{O}^{+} \rightarrow$ $\mathrm{CH}_{3}-\mathrm{Hg}-\mathrm{OH}_{2}^{+}+\mathrm{CH}_{4}$ is spontaneous and has a large equilibrium constant at room temperature, the reaction $\mathrm{CH}_{3}-\mathrm{Hg}-\mathrm{CH}_{3}+\mathrm{H}_{2} \mathrm{O} \rightarrow \mathrm{CH}_{3}-\mathrm{Hg}-\mathrm{OH}+\mathrm{CH}_{4}$ would require higher temperatures to produce noticeable concentrations of the products. Also, the fourth row (labeled system-IV) in Table 5 provides the data for complex formation of $\left[\mathrm{Cl}-\mathrm{Hg}-\mathrm{Cl} \bullet \mathrm{H}_{5} \mathrm{O}_{2}\right]^{+}$as shown in Figure 8 (panel-B).

\section{Discussion}

The goal of the present theoretical study is to explore possible mechanisms that can contribute to the chemical degradation of DMHg $\left(\mathrm{CH}_{3}-\mathrm{Hg}-\mathrm{CH}_{3}\right)$. Furthermore, we also explore additional $\mathrm{Hg}$-containing compounds, namely $\mathrm{Cl}-\mathrm{Hg}-\mathrm{Cl}$ and $\mathrm{CH}_{3}-\mathrm{Hg}-\mathrm{Cl}$, focusing on their binding strength with respect to water and hydronium ions as well as ions of $\mathrm{OH}^{-}, \mathrm{Cl}^{-}$and $\mathrm{NH}_{4}{ }^{+}$. The present work examines energetics and thermochemistry of degradation pathways of $\mathrm{X}-\mathrm{Hg}-\mathrm{Y}$ complexes (here, each symbol $\mathrm{X}$ and $\mathrm{Y}$ represents either $\mathrm{CH}_{3}$ or $\mathrm{Cl}$ ). As noted earlier, the present theoretical work is primarily focused on the exploration of the interaction of $\left(\mathrm{CH}_{3}-\mathrm{Hg}-\mathrm{CH}_{3}\right)$ with water molecules and hydronium ions which relates closely with $\mathrm{pH}$ levels and the stability of DMHg in

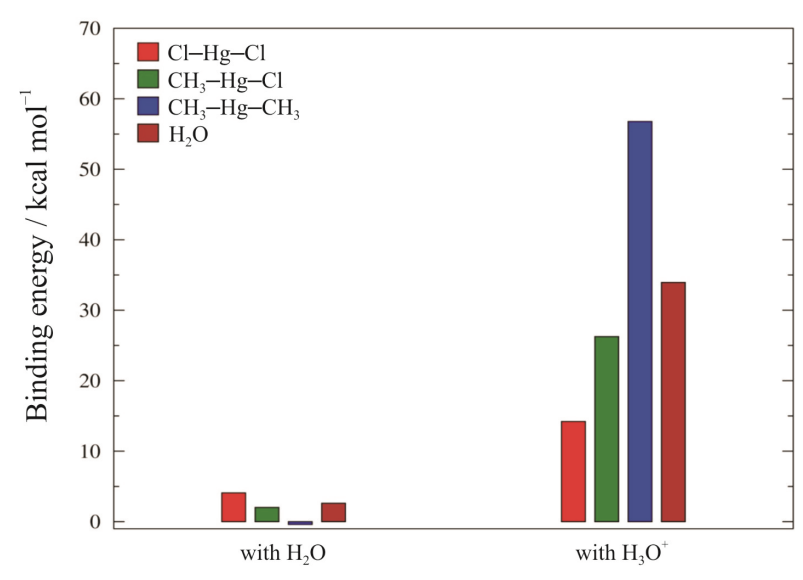

Figure 7. Comparison of binding energies (see text) of the selected mercury-containing species $(\mathrm{X}-\mathrm{Hg}-\mathrm{Y})$ with ligands $\mathrm{L}\left(\mathrm{L}=\mathrm{H}_{2} \mathrm{O}\right.$ and $\left.\mathrm{H}_{3} \mathrm{O}^{+}\right)$.

aqueous environments. The current work shows that the DMHg is highly unstable with respect to $\mathrm{H}_{3} \mathrm{O}^{+}$and decomposes readily while the presence of other ions, like $\mathrm{OH}^{-}, \mathrm{Cl}^{-}$and $\mathrm{NH}_{4}^{+}$, has a somewhat weaker effect on the stability of DMHg. Although the present study corresponds to gas-phase conditions, the instability of DMHg with respect to the hydronium ion clearly implies that in aqueous environment the rate of degradation of $\mathrm{DMHg}$ should increase as value of $\mathrm{pH}$ gets smaller. Manifestly, our result is in accord with the experimental observations regarding the dependence of increased instability of DMHg with lower $\mathrm{pH}$ levels in

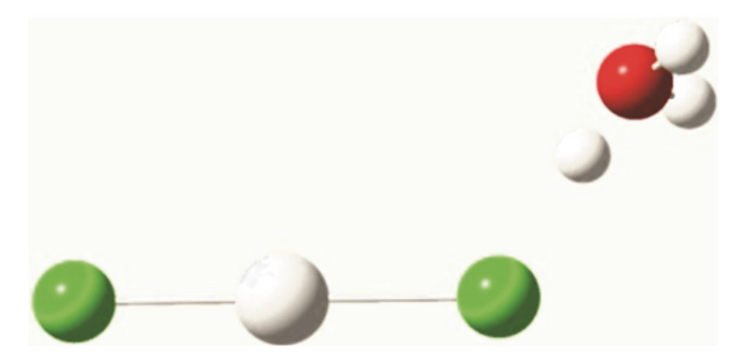

(A) $\mathrm{Cl}-\mathrm{Hg}-\mathrm{Cl} \bullet \mathrm{H}_{3} \mathrm{O}^{+}$

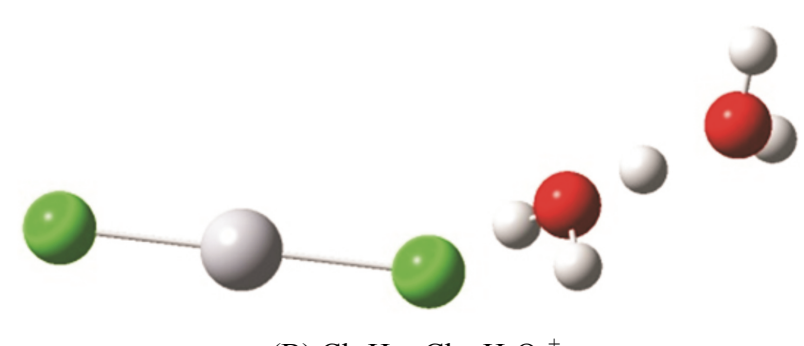

(B) $\mathrm{Cl}-\mathrm{Hg}-\mathrm{Cl} \bullet \mathrm{H}_{5} \mathrm{O}_{2}^{+}$

Figure 8. Comparison of the bound complexes resulting from the interaction of $\mathrm{Cl}-\mathrm{Hg}-\mathrm{Cl}$ with $\mathrm{H}_{3} \mathrm{O}^{+}$(panel A) and $\mathrm{H}_{5} \mathrm{O}_{2}^{+}$ (panel B). 
aqueous environment found in literature. ${ }^{32-34} \mathrm{We}$ also demonstrate that $\mathrm{Cl}-\mathrm{Hg}-\mathrm{CH}_{3}$ which has only one methyl group is much more stable with respect to the hydronium ion as compared to the DMHg compound. This result correlates well with a recent report by Korbas et $a l .{ }^{14}$ which suggests that dimethylmercury should be more susceptible to $\mathrm{C}-\mathrm{Hg}$ protonolysis than monomethyl species based solely on the examination of the distribution of Mulliken atomic charges. Manifestly, the data above sheds some light regarding the rapid demethylation of dimethylmercury to monomethyl species reported by Ostlund ${ }^{27}$ in his laboratory experiments. Our conclusion regarding the instability of DMHg with respect to $\mathrm{H}_{3} \mathrm{O}^{+}$which proceeds without a detectable barrier to yield the products $\left[\mathrm{CH}_{3}-\mathrm{Hg}-\mathrm{OH}_{2}\right]^{+}$and $\mathrm{CH}_{4}$, correlates closely with the result of $\mathrm{Ni}$ et $a l .{ }^{37}$ who found that, in the gas phase, backside protonolysis of the $\mathrm{Hg}-\mathrm{C}$ bond of $\left[\mathrm{CH}_{3} \mathrm{Hg}(\mathrm{SH})_{2}\right]^{-}$by the ammonium ion $\left(\mathrm{NH}_{4}{ }^{+}\right)$occurs without a detectable barrier as well.

\section{CONCLUSIONS}

The goal of the present investigation is to explore the stability of several mercury-containing compounds of the general form $\mathrm{X}-\mathrm{Hg}-\mathrm{Y}\left(\mathrm{X}=\mathrm{CH}_{3}, \mathrm{Cl}\right.$ and $\mathrm{Y}=\mathrm{CH}_{3}$, $\mathrm{Cl})$ with respect to several small molecules which we call ligands L for simplicity that are frequently found in aqueous environments. We consider a set of neutral ligands $\left(\mathrm{L}=\mathrm{H}_{2} \mathrm{O}\right.$ or $\left.\mathrm{NH}_{3}\right)$ and a set of charged ligands $\left(\mathrm{L}=\mathrm{H}_{3} \mathrm{O}^{+}, \mathrm{OH}^{-}, \mathrm{Cl}^{-}\right.$and $\left.\mathrm{NH}_{4}{ }^{+}\right)$. We find that, in general, ionic ligands form much more strongly bound complexes with $\mathrm{X}-\mathrm{Hg}-\mathrm{Y}$ compounds of the form $[\mathrm{X}-\mathrm{Hg}-\mathrm{Y} \bullet \mathrm{L}]^{\mathrm{q}}$ compared to their neutral counterparts (here $\mathrm{q}$ indicates the electric charge of the complex). The largest energy lowering was found for $\mathrm{CH}_{3}-\mathrm{Hg}-\mathrm{CH}_{3}+\mathrm{OH}^{-} \rightarrow$ $\left[\mathrm{CH}_{3}-\mathrm{Hg}-\mathrm{CH}_{3} \bullet \mathrm{OH}\right]^{-}$and $\mathrm{CH}_{3}-\mathrm{Hg}-\mathrm{CH}_{3}+\mathrm{H}_{3} \mathrm{O}^{+} \rightarrow$ $\mathrm{CH}_{3}-\mathrm{Hg}-\mathrm{OH}_{2}^{+}+\mathrm{CH}_{4}$ reactions with large equilibrium constants at room temperature in both cases. The weakly bound-complex $\left[\mathrm{CH}_{3}-\mathrm{Hg}-\mathrm{OH}_{2} \bullet \mathrm{CH}_{4}\right]^{+}$has the binding energy of only $1.4 \mathrm{kcal} / \mathrm{mol}$ with respect to the dissociation fragments $\left[\mathrm{CH}_{3}-\mathrm{Hg}-\mathrm{OH}_{2}\right]^{+}$and $\mathrm{CH}_{4}$ that is $59.2 \mathrm{kcal} / \mathrm{mol}$ lower than the $\left[\mathrm{CH}_{3}-\mathrm{Hg}-\mathrm{CH}_{3}\right.$ plus $\left.\mathrm{H}_{3} \mathrm{O}^{+}\right]$ system. The $\left[\mathrm{CH}_{3}-\mathrm{Hg}-\mathrm{CH}_{3} \bullet \mathrm{OH}\right]^{-}$complex is 26.0 $\mathrm{kcal} / \mathrm{mol}$ lower than the system composed of noninteracting fragments $\mathrm{CH}_{3}-\mathrm{Hg}-\mathrm{CH}_{3}$ and $\mathrm{OH}^{-}$.

Overall, our study indicates that dimethylmercury is unstable in low-pH aquatic environments readily decomposing into $\left[\mathrm{CH}_{3}-\mathrm{Hg}-\mathrm{OH}_{2}\right]^{+}$and $\mathrm{CH}_{4}$. This work provides the quantitative data for explaining the experimental observations reporting that low-pH levels of aqueous medium favor a rapid decomposition of $\mathrm{CH}_{3}-\mathrm{Hg}-\mathrm{CH}_{3}$ (see Refs. 32-34). Our result is in accord with the earlier findings by Tossell who noted the remarkable stability of $\left[\mathrm{CH}_{3}-\mathrm{Hg}-\mathrm{OH}_{2}\right]^{+}$compound in water systems in his earlier investigations ${ }^{44}$ of photo- decomposition of methyl $\mathrm{Hg}$ complexes. On the other hand, our study shows that high-pH levels in aqueous environment would favor strongly-bound complexes of $\left[\mathrm{CH}_{3}-\mathrm{Hg}-\mathrm{CH}_{3} \bullet \mathrm{OH}\right]^{-}$species.

Supplementary Materials. - Supporting informations to the paper are enclosed to the electronic version of the article. These data can be found on the website of Croatica Chemica Acta (http://public.carnet.hr/ccacaa).

Acknowledgements. This work is dedicated to Professor Douglas J. Klein (on the occasion of his 70-th birthday) whom the author has had a great pleasure of knowing for many years. During this time, the author has been impressed by Professor Klein's scientific originality and depth in solving numerous problems in chemistry, physics and mathematics of remarkable diversity. The author has no doubt that many significant breakthrough research papers authored by Professor Klein will appear in scientific literature in the near future. The author has a great appreciation to Professor Klein for his role as a mentor during the author's early scientific carrier. The author acknowledges useful discussions with Professor Gustavo E. Scuseria, Dr. Kousik Samanta and Dr. Carlos Jiménez-Hoyos.

\section{REFERENCES}

1. P. Pyykkö, Ann. Rev. Phys. Chem. 63 (2012) 45.

2. L. J. Norrby, J. Chem. Ed. 68 (1991) 110.

3. M. D. Morse, Chem. Rev. 86 (1986) 1049.

4. W. B. Jensen, J. Chem. Ed. 80 (2003) 952.

5. W. B. Jensen, J. Chem. Ed. 85 (2008) 1182.

6. X. F. Wang, L. Andrews, S. Riedel, and M. Kaupp, Angew. Chem. Int. Ed. 46 (2007) 8371.

7. E. Pahl, D. Figgen, C. Thierfelder, K. A. Peterson, F. Calvo, and P. Schwerdtfeger, J. Chem. Phys. 132 (2010) 114301.

8. M. H. Keating, Mercury Study Report to Congress, Vol. 1: Executive Summary, United States Environmental Protection Agency, 1997.

9. T. W. Clarkson and L. Magos, Crit. Rev. Toxicol. 36 (2006) 609.

10. R. A. Goyer, Toxological effects of Methylmercury, National Academy Press: Washington DC, 2000.

11. H. H. Harris, I. J. Pickering, and N. G. Graham, Science 301 (2003) 1203.

12. D. Mergler, H. A. Anderson, L. H. M. Chan, K. R. Mahaffey, M. Murray, M. Sakamoto, and A. H. Stern, Ambio 36 (2007) 3.

13. D. Cremer, E. Kraka, and M. Filatov, ChemPhysChem 9 (2008) 2510.

14. M. Korbas, J. L. O’Donoghue, G. E. Watson, I. J. Pickering, S. P. Singh, G. J. Myers, T. W. Clarkson, and G. N. George, ACS Chem. Neurosci. 1 (2010) 810.

15. V. Barone, A. Bencini, F. Totti, and M. G. Uytterhoeven, Organometalics 15 (1995) 1465.

16. M. J. Moore, M. D. Distefano, L. D. Zydowski, R. T. Cummings, and W. T. Walsh, Acc. Chem. Res. 23 (1990) 301.

17. G. Topping and I. M. Davies, Nature 290 (1981) 243.

18. I. Lehnherr, V. L. St. Louis, H. Hintelmann, and J. L. Kirk, Nature Geoscience 4 (2011) 298.

19. J. J. Alberts, J. E. Schindler, R. W. Miller, and D. E. Nutter Jr., Science 184 (1974) 895.

20. B. Gu, Y. Bian, C. L. Miller, W. Dong, X. Jiang, and L. Liang, Proc. Nat. Acad. Sciences (USA) 108 (2011) 1479.

21. A. Bollen and H. Biester, Water Air Soil Pollut. 219 (2011) 175. 
22. C. H. Conaway, F. J. Black, M. Gault-Ringold, J. T. Pennington, F. P. Chavez, and A. R. Flegal, Environ. Sci. Technol. 43 (2009) 1305 .

23. W. F. Fitzgerald, C. H. Lamborg, and C. R. Hammerschmidt, Chem. Rev. 107 (2007) 641.

24. R. P. Mason and W. F. Fitzgerald, Deep Sea Res. Part I 40 (1993) 1897

25. N. M. Lawson and R. P. Mason, Biogeochemistry 40 (1998) 235.

26. R. Pongratz and K. G. Heuman, Chemosphere 39 (1999) 89.

27. K. Ostlund, Acta Pharmacol. Toxicol. 27 (Suppl) (1969) 1.

28. J. Mink and B. Gellai, J. Organomet. Chem. 66 (1974) 1.

29. A. M. W. Bakke, J. Mol. Spectrosc. 41 (1972) 1.

30. R. E. Rebbert and P. Ausloos, J. Am. Chem. Soc. 85 (1963) 3086.

31. H. Niki, P. D. Maker, C. M. Savage, and L. P. Breitenbach, J. Phys. Chem. 87 (1983) 4978.

32. N. L. Wolfe, R. G. Zepp, J. A. Gordon, and G. L. Baughman, Chemosphere 2 (1972) 147.

33. T. Fagerström and A. Jernelöv, Water Research 6 (1972) 1193.

34. M. R. Winfrey and J. W. M. Rudd, Environ. Toxicol. Chem. 9 (1990) 853

35. C. J. Lin and S. O. Pehkonen, Atmos. Environ. 33 (1999) 2067.

36. B. Ni, J. R. Kramer, R. A. Bell, and N. H. Werstiuk, J. Phys. Chem. A 110 (2006) 9451.

37. A. F. Khalizov, B. Viswanathan, P. Larregaray, and P. Ariya, $J$. Phys. Chem. A 107 (2003) 6360.

38. B. C. Shepler, A. D. Wright, N. B. Balabanov, and K. A. Peterson, J. Phys. Chem. A 111 (2007) 11342.

39. H.-C. Tai and C. Lim, J. Phys. Chem. A 110 (2006) 452.

40. X. Li, R.-Z. Liao, W. Zhou, and G. Chen, Phys. Chem. Chem. Phys. 12 (2010) 3961.

41. L. Castro, A. Dommergue, A. Renard, C. Ferrari, A. RamirezSolis, and L. Maron, Phys. Chem. Chem. Phys. 13 (2011) 16772.

42. D. Majumdar, S. Rosak, and J. Leszczynski, Chem. Phys. Lett. 501 (2011) 308.

43. A. T. Afaneh, G. Schereckenbach, and F. Wang, Theor. Chem. Acc. 131 (2012) 1174.

44. J. A. Tossell, J. Phys. Chem. A 102 (1998) 3587.

45. P. Sellers, S. A. Kelley, J. W. M. Rudd, and A. R. Mac-Hutchon, Nature 380 (1996) 694.

46. S. F. Boys and F. Bernardi, Mol. Phys. 19 (1970) 553.
47. www.theochem.uni-stuttgart.de/pseudopotentials

48. D. Figgen, G. Rauhut, M. Dolg, and H. Stoll, Chem. Phys. 311 (2005) 227.

49. M. J. Frisch, G. W. Trucks, H. B. Schlegel, G. E. Scuseria, M. A. Robb, J. R. Cheeseman, G. Scalmani, V. Barone, et al. Gaussian 09, Revision A.02; Gaussian Inc.: Wallingford CT, 2009.

50. L. Bytautas, J. M. Bowman, X. Huang, and A.J.C. Varandas, Adv. Phys. Chem. 2012 (2012) 679869

51. L. Bytautas, "Theoretical Studies of Chemical Reactions", Ph. D. Thesis, Vanderbilt University, Nashville, TN, USA (1996).

52. H. B. Schlegel, J. Comp. Chem. 24 (2003) 1514.

53. N. B. Balabanov and K. A. Peterson, J. Chem. Phys. 119 (2003) 12271.

54. B. J. Aylett, Comprehensive Inorganic Chemistry, Pergamon Press: Elmsford, NY, 1973, Vol. 3.

55. D. M. Adams and D. J. Hills, J. Chem. Soc. Dalton Trans. (1978) 776 .

56. W. Gordy, J. Sheridan, J. Chem. Phys. 22 (1954) 92.

57. M. W. Feyereisen, D. Feller, and D. A. Dixon, J. Phys. Chem. 100 (1996) 2993.

58. J. M. Headrick, E.G. Dicken, R. S. Walters, N. I. Hammer, R. A. Christie, J. Cui, E. M. Myshakin, M. A. Duncan, M. A. Johnson, and K. D. Jordan, Science 308 (2005) 1765.

59. T. L. Guasco, M. A. Johnson, and A. B. McCoy, J. Phys. Chem. A 115 (2011) 5847.

60. S. G. Olesen, T. L. Guasco, J. R. Roscioli, and M. A. Johnson, Chem. Phys. Lett. 509 (2011) 89.

61. X. Huang, B. J. Braams, and J. M. Bowman, J. Chem. Phys. 122 (2005) 044308.

62. D. G. Truhlar and B. C. Garrett, Acc. Chem. Res. 13 (1980) 440.

63. D. G. Truhlar, B. C. Garrett, and S. J. Klippenstein, J. Phys. Chem. 100 (1996) 12771.

64. R. E. Stanton and J. W. McIver Jr., J. Am. Chem. Soc. 97 (1975) 3632 .

65. L. Bytautas and D. J. Klein, Int. J. Quantum Chem. 70 (1998) 205.

66. T. Uchiyama, T. Miura, H. Takeuchi, T. Dairaku, T. Komuro, T. Kawamura, Y. Kondo, L. Benda, V. Sychrovský, P. Bouř, I. Okamoto, A. Ono, and Y. Tanaka, Nucleic Acids Res. 40 (2012) 5766 . 
SUPPLEMENTAL MATERIAL

\section{Stability of dimethylmercury and related mercury-containing compounds with respect to selected chemical species found in aqueous environment}

\section{Laimutis Bytautas}

Department of Chemistry, Rice University, Houston, Texas 77005, USA ${ }^{\text {a-c) }}$

a) Present address: Galveston College, Department of Chemistry, 4015 Avenue Q, Galveston, TX, 77550, USA.

b) Email: bytautas777@gmail.com

c) This work is dedicated to Professor Douglas J. Klein on the occasion of his 70-th birthday. 


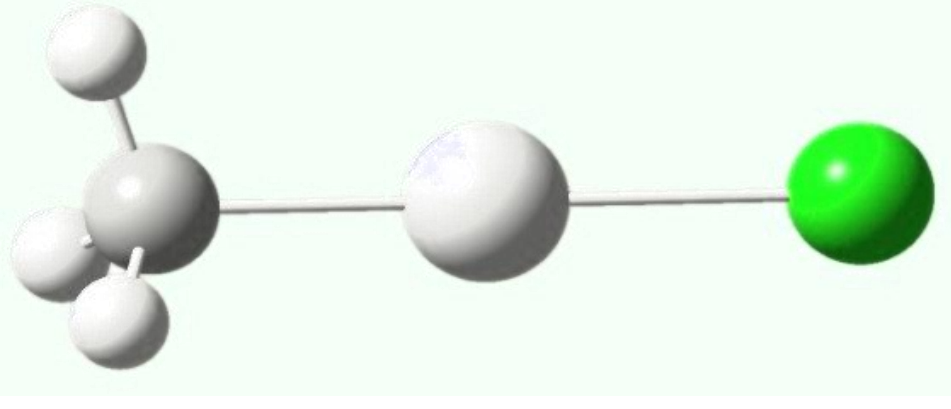

Table SI. Comparison between calculated and experimental ${ }^{\text {a) }}$ bond distances (in $\AA$ ) and angles (in degree) for the optimized geometries $\mathrm{CH}_{3}-\mathrm{Hg}-\mathrm{Cl}$.

\begin{tabular}{llll}
\hline \multicolumn{1}{c}{ Geometry } & PBE & MP2 & Experiment \\
\hline $\mathrm{r}(\mathrm{Hg}-\mathrm{Cl})$ & 2.331 & 2.327 & 2.282 \\
$\mathrm{r}(\mathrm{Hg}-\mathrm{C})$ & 2.075 & 2.075 & 2.061 \\
$\operatorname{angle}(\mathrm{C}-\mathrm{Hg}-\mathrm{Cl})$ & 180.0 & 180.0 & 180.0 \\
& & & \\
\hline
\end{tabular}

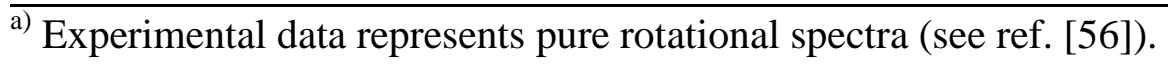




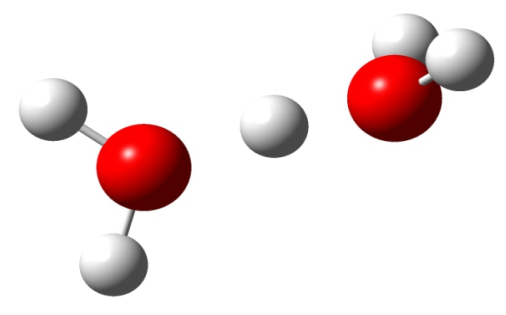

Table SII. Comparison of results ${ }^{\text {a) }}$ obtained by methods used in the present study $(6-31 G(d, p)$ basis sets) to the benchmark literature value for the dissociation energy $\left(\mathrm{D}_{\mathbf{e}}\right)$ of $\mathrm{H}_{5} \mathrm{O}_{2}{ }^{+}$. Total electronic energies are listed in hartree while dissociation energies are listed in $\mathrm{kcal} / \mathrm{mol}$.

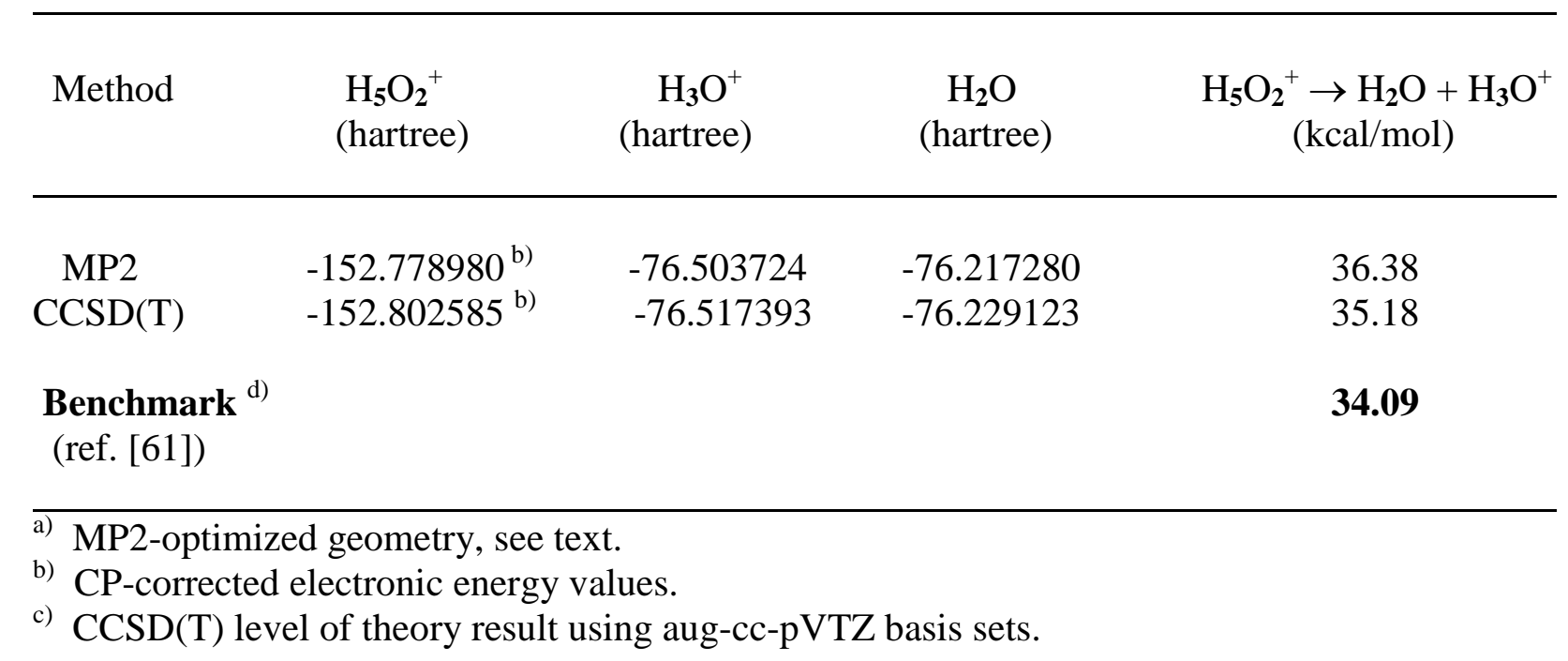


TABLE SIII. $\mathrm{H}_{2} \mathrm{O}$ interaction with $\mathrm{X}-\mathrm{Hg}-\mathrm{Y}$. Total electronic energies at CCSD(T) level of theory, zero-point-energies (ZPE) and Gibbs free energies (298.15 K and $1 \mathrm{~atm})$ at MP2 level of theory. Energy units are in hartree.

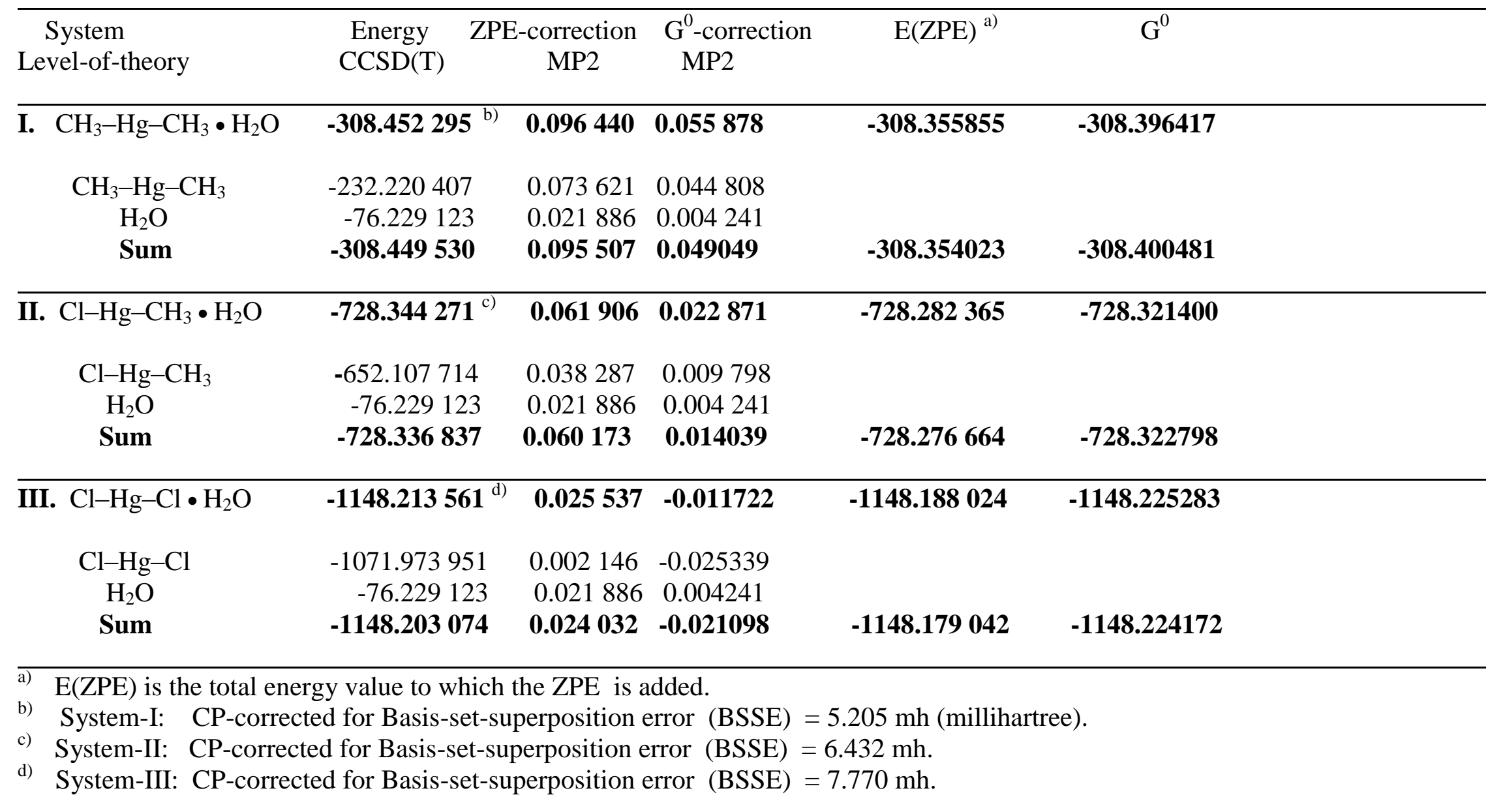


Table SIV. Interaction of $\mathrm{CH}_{3}-\mathrm{Hg}-\mathrm{CH}_{3}$ with $\mathrm{NH}_{3}$ and $\mathrm{H}_{2} \mathrm{O}$. Total energies at CCSD(T) level of theory, zero-point energies and Gibbs free energies (298.15 K and $1 \mathrm{~atm}$ ) at MP2 level of theory. The counterpoise (CP) correction has been applied.

\begin{tabular}{|c|c|c|c|c|c|}
\hline $\begin{array}{c}\text { System } \\
\text { Level-of-theory }\end{array}$ & $\begin{array}{r}\text { Energy } \\
\text { CCSD }(\mathrm{T})\end{array}$ & $\begin{array}{l}\mathrm{ZPE} \\
\mathrm{MP} 2\end{array}$ & $\begin{array}{c}\mathrm{G}^{0} \text {-correction } \\
\text { MP } 2\end{array}$ & $\mathrm{E}(\mathrm{ZPE})^{\mathrm{a})}$ & $\mathrm{G}^{0}$ (free energy) \\
\hline $\mathrm{CH}_{3}-\mathrm{Hg}-\mathrm{CH}_{3} \bullet \mathrm{NH}_{3}$ & $-288.624053^{b)}$ & 0.110216 & 0.069312 & -288.513837 & -288.554741 \\
\hline $\mathrm{CH}_{3}-\mathrm{Hg}-\mathrm{CH}_{3}$ & -232.220407 & 0.073621 & 0.044808 & & \\
\hline $\mathrm{NH}_{3}$ & -56.400009 & 0.035466 & 0.017442 & & \\
\hline Sum & -288.620416 & 0.109087 & 0.062250 & -288.511329 & -288.558166 \\
\hline
\end{tabular}

a) $\mathrm{E}(\mathrm{ZPE})$ is the total energy value to which the ZPE is added.

b) $\mathrm{CP}$-corrected for Basis-set-superposition error $(\mathrm{BSSE})=5.286 \mathrm{mh}$. 
Table SV. Complexes resulting from $\mathrm{CH}_{3}-\mathrm{Hg}-\mathrm{CH}_{3}$ interaction with selected ionic Ligands. Reported results include energy differences based on electronic total energies, the zero-point-energy (ZPE) corrected values as well as Gibbs free energy change of complex formation ( $\mathrm{T}=298.15 \mathrm{~K}$ and $1 \mathrm{~atm})$. The counterpoise correction has been applied.

\begin{tabular}{|c|c|c|c|c|c|c|}
\hline $\begin{array}{c}\text { System } \\
\text { Level-of-theory }\end{array}$ & $\begin{array}{c}\text { Total Energy } \\
\text { CCSD(T)/hartree }\end{array}$ & $\begin{array}{c}\text { ZPE } \\
\text { MP2/hartree }\end{array}$ & $\begin{array}{c}\mathrm{G}^{0} \\
\text { MP2/hartree }\end{array}$ & $\begin{array}{c}\Delta \mathrm{E}^{\mathrm{a})} \\
\text { millihartree }\end{array}$ & $\begin{array}{l}\Delta \mathrm{E}(\mathrm{ZPE})^{\mathrm{b})} \\
\text { millihartree }\end{array}$ & $\begin{array}{l}\Delta \mathrm{G}^{0} \\
\text { millihartree }\end{array}$ \\
\hline I. $\left[\mathrm{CH}_{3}-\mathrm{Hg}-\mathrm{CH}_{3} \cdot \mathrm{OH}\right]^{-}$ & $-307.795063^{c)}$ & 0.084098 & 0.048759 & -43.523 & -41.419 & -31.672 \\
\hline $\mathrm{CH}_{3}-\mathrm{Hg}-\mathrm{CH}_{3}$ & -232.220407 & 0.073621 & 0.044808 & & & \\
\hline $\mathrm{OH}^{-}$ & -75.531144 & 0.008373 & -0.007900 & & & \\
\hline Sum & -307.751540 & 0.081994 & 0.036908 & & & \\
\hline II. $\left[\mathrm{CH}_{3}-\mathrm{Hg}-\mathrm{CH}_{3} \bullet \mathrm{Cl}\right]^{-}$ & $-691.903163^{d)}$ & 0.071959 & 0.034664 & -19.203 & -20.865 & -13.667 \\
\hline $\mathrm{CH}_{3}-\mathrm{Hg}-\mathrm{CH}_{3}$ & -232.220407 & 0.073621 & 0.044808 & & & \\
\hline $\mathrm{Cl}^{-}$ & 459.663564 & 0.0 & -0.015680 & & & \\
\hline Sum & -691.883960 & 0.073621 & 0.029128 & & & \\
\hline III. $\left[\mathrm{CH}_{3}-\mathrm{Hg}-\mathrm{CH}_{3} \bullet \mathrm{NH}_{4}\right]^{+}$ & $-288.982493^{\mathrm{e})}$ & 0.125568 & 0.086803 & -9.762 & -8.697 & 0.997 \\
\hline $\mathrm{CH}_{3}-\mathrm{Hg}-\mathrm{CH}_{3}$ & -232.220407 & 0.073621 & 0.044808 & & & \\
\hline $\mathrm{NH}_{4}^{+}$ & -56.752324 & 0.050882 & 0.031236 & & & \\
\hline Sum & -288.972731 & 0.124503 & 0.076044 & & & \\
\hline
\end{tabular}

\footnotetext{
a) $\triangle \mathrm{E}$ is $\mathrm{CCSD}(\mathrm{T})$ energy difference between a bound $\left[\mathrm{CH}_{3}-\mathrm{Hg}-\mathrm{CH}_{3} \bullet\right.$ Ligand] system and individual fragments, $\mathrm{CH}_{3}-\mathrm{Hg}-\mathrm{CH}_{3}$ and $\mathrm{Ligand}$.

b) $\triangle \mathrm{E}(\mathrm{ZPE})$ represents $\triangle \mathrm{E}$ with an additional correction due to $\mathrm{ZPE}$.

c) System-I: CP-corrected for Basis-set-superposition error (BSSE) $=54.186 \mathrm{mh}$.

d) System-II: CP-corrected for Basis-set-superposition error $(\mathrm{BSSE})=13.812 \mathrm{mh}$.

e) System-III: CP-corrected for Basis-set-superposition error $(\mathrm{BSSE})=1.821 \mathrm{mh}$.
} 
Table SVI. $\mathrm{CH}_{3}-\mathrm{Hg}-\mathrm{CH}_{3}$ interaction with selected ionic Ligands. Total energies at $\mathrm{CCSD}(\mathrm{T})$ level of theory and zero-point energies at MP2 level of theory for various decomposition fragments resulting from $\mathrm{CH}_{3}-\mathrm{Hg}-\mathrm{CH}_{3}$ and $\mathrm{H}_{3} \mathrm{O}^{+}$interaction. No counterpoise $(\mathrm{CP})$ correction has been applied unless noted otherwise.

\begin{tabular}{|c|c|c|c|c|c|c|}
\hline $\begin{array}{l}\text { System } \\
\text { Level-of-theory }\end{array}$ & $\begin{array}{c}\text { Total Energy } \\
\text { CCSD(T)/hartree }\end{array}$ & $\begin{array}{c}\text { ZPE } \\
\text { MP2/hartree }\end{array}$ & $\begin{array}{c}\mathrm{G}^{0} \\
\mathrm{MP} 2 / \text { hartree }\end{array}$ & $\begin{array}{c}\Delta \mathrm{E}^{\mathrm{a})} \\
\text { millihartree }\end{array}$ & $\begin{array}{l}\Delta \mathrm{E}(\mathrm{ZPE})^{\mathrm{b})} \\
\text { millihartree }\end{array}$ & $\begin{array}{c}\Delta \mathrm{G}^{0} \\
\text { millihartree }\end{array}$ \\
\hline I. $\begin{array}{c}\mathrm{CH}_{3}-\mathrm{Hg}-\mathrm{CH}_{3} \\
\mathrm{H}_{3} \mathrm{O}^{+} \\
\text {Sum }\end{array}$ & $\begin{array}{r}-232.220407 \\
-76.517394 \\
\mathbf{- 3 0 8 . 7 3 7 8 0 1}\end{array}$ & $\begin{array}{l}0.073621 \\
0.035287 \\
\mathbf{0 . 1 0 8 9 0 8}\end{array}$ & $\begin{array}{l}0.044808 \\
0.016154 \\
\mathbf{0 . 0 6 0 9 6 2}\end{array}$ & $\mathbf{0 . 0}$ & $\mathbf{0 . 0}$ & $\mathbf{0 . 0}$ \\
\hline II. $\begin{array}{c}{\left[\mathrm{CH}_{3}-\mathrm{Hg}\right]^{+}} \\
\mathrm{CH}_{4} \\
\mathrm{H}_{2} \mathrm{O} \\
\text { Sum }\end{array}$ & $\begin{array}{r}-192.148639 \\
-40.388354 \\
-76.229124 \\
\mathbf{- 3 0 8 . 7 6 6 ~ 1 1 6}\end{array}$ & $\begin{array}{l}0.036718 \\
0.046537 \\
0.021886 \\
\mathbf{0 . 1 0 5} \mathbf{1 4 1}\end{array}$ & $\begin{array}{l}0.011323 \\
0.029234 \\
0.004241 \\
\mathbf{0 . 0 4 4 7 9 8}\end{array}$ & -28.315 & -32.082 & -44.479 \\
\hline 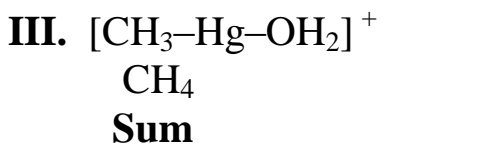 & $\begin{array}{l}-268.440425 \\
-40.388354 \\
\mathbf{- 3 0 8 . 8 2 8 7 7 9}\end{array}$ & $\begin{array}{l}0.061736 \\
0.046537 \\
\mathbf{0 . 1 0 8} 273\end{array}$ & $\begin{array}{l}0.029141 \\
0.029234 \\
\mathbf{0 . 0 5 8 3 7 5}\end{array}$ & -90.978 & -91.613 & -93.565 \\
\hline $\begin{array}{l}\text { System } \\
\text { Level-of-theory }\end{array}$ & $\begin{array}{c}\text { Total Energy } \\
\text { CCSD(T)/hartree }\end{array}$ & $\begin{array}{c}\text { ZPE } \\
\text { MP2/hartree }\end{array}$ & $\begin{array}{l}\mathrm{G}^{0} \\
\mathrm{MP} 2 / \text { hartree }\end{array}$ & $\begin{array}{c}\Delta \mathrm{E}^{\mathrm{a})} \\
\text { millihartree }\end{array}$ & $\begin{array}{l}\Delta \mathrm{E}(\mathrm{ZPE})^{\mathrm{b})} \\
\text { millihartree }\end{array}$ & $\begin{array}{c}\Delta \mathrm{G}^{0} \\
\text { millihartree }\end{array}$ \\
\hline IV. $\left[\mathrm{CH}_{3}-\mathrm{Hg}-\mathrm{OH}_{2} \bullet \mathrm{CH}_{4}\right]^{+}$ & $-308.832815^{d)}$ & 0.109636 & 0.064586 & -3.619 & -2.256 & 2.592 \\
\hline $\begin{array}{c}\text { V. The geometries taken fr } \\
{\left[\mathrm{CH}_{3}-\mathrm{Hg}-\mathrm{OH}_{2}\right]^{+}} \\
\mathrm{CH}_{4} \\
\text { Sum: }\end{array}$ & $\begin{array}{c}\text { m System-IV and Z } \\
-268.440302 \\
-40.388894 \\
\mathbf{- 3 0 8 . 8 2 9} 196\end{array}$ & $\begin{array}{c}\text { Es for }\left[\mathrm{CH}_{3}-\mathrm{H}\right. \\
0.061736 \\
0.046537 \\
\mathbf{0 . 1 0 8 2 7 3}\end{array}$ & $\begin{array}{l}\left.-\mathrm{OH}_{2}\right]^{+} \text {and } \mathrm{CH}_{4} \\
0.029141 \\
0.029234 \\
\mathbf{0 . 0 5 8 3 7 5}\end{array}$ & ${ }_{4}$ taken from Sy: & tem-III) & $\mathbf{0 . 0}$ \\
\hline
\end{tabular}

$\triangle \mathrm{E}$ is $\mathrm{CCSD}(\mathrm{T})$ energy with respect to the energy of System-I.

b) $\triangle \mathrm{E}(\mathrm{ZPE})$ represents an additional correction to $\triangle \mathrm{E}$ that is due to $\mathrm{ZPE}$.

c) $\triangle \mathrm{E}$ is $\mathrm{CCSD}(\mathrm{T})$ energy difference between a bound $\left[\mathrm{CH}_{3}-\mathrm{Hg}-\mathrm{CH}_{3} \bullet\right.$ Ligand] system and individual fragments, $\mathrm{CH}_{3}-\mathrm{Hg}-\mathrm{CH}_{3}$ and $\mathrm{Ligand}$.

d) System-IV: CP-corrected for Basis-set-superposition error (BSSE) $=1.312 \mathrm{mh}$. 
Table SVII. Hydronium ion interaction with X-Hg-Y. Total energies at CCSD(T) level of theory and zero-point energies at MP2 level of theory.

\begin{tabular}{|c|c|c|c|c|c|c|}
\hline $\begin{array}{l}\text { System } \\
\text { Level-of-theory }\end{array}$ & $\begin{array}{c}\text { Total Energy } \\
\text { CCSD(T)/hartree }\end{array}$ & $\begin{array}{c}\text { ZPE } \\
\text { MP2/hartree }\end{array}$ & $\begin{array}{c}\mathrm{G}^{0} \\
\text { MP2/hartree }\end{array}$ & $\begin{array}{c}\Delta \mathrm{E}^{\mathrm{a})} \\
\text { millihartree }\end{array}$ & $\begin{array}{l}\Delta \mathrm{E}(\mathrm{ZPE})^{\mathrm{b})} \\
\text { millihartree }\end{array}$ & $\Delta \mathrm{G}^{0}$ \\
\hline I. $\left[\mathrm{CH}_{3}-\mathrm{Hg}-\mathrm{OH}_{2} \bullet \mathrm{CH}_{4}\right]^{+}$ & $-308.832815^{c)}$ & 0.109636 & 0.064586 & -95.014 & -94.286 & -91.39 \\
\hline $\begin{array}{c}\mathrm{CH}_{3}-\mathrm{Hg}-\mathrm{CH}_{3} \\
\mathrm{H}_{3} \mathrm{O}^{+} \\
\text {Sum }\end{array}$ & $\begin{array}{r}-232.220407 \\
-76.517394 \\
\mathbf{- 3 0 8 . 7 3 7 8 0 1}\end{array}$ & $\begin{array}{l}0.073621 \\
0.035287 \\
\mathbf{0 . 1 0 8} 908\end{array}$ & $\begin{array}{l}0.044808 \\
0.016154 \\
\mathbf{0 . 0 6 0 9 6 2}\end{array}$ & & & \\
\hline 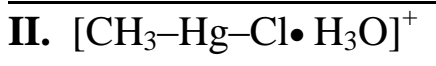 & $-728.669346^{d)}$ & 0.073697 & - & -44.238 & -44.115 & \\
\hline $\begin{array}{c}\mathrm{CH}_{3}-\mathrm{Hg}-\mathrm{Cl} \\
\mathrm{H}_{3} \mathrm{O}^{+} \\
\text {Sum }\end{array}$ & $\begin{array}{r}-652.107714 \\
-76.517394 \\
-\mathbf{7 2 8 . 6 2 5} 108\end{array}$ & $\begin{array}{l}0.038287 \\
0.035287 \\
\mathbf{0 . 0 7 3} 574\end{array}$ & & & & \\
\hline III. $\left[\mathrm{Cl}-\mathrm{Hg}-\mathrm{Cl} \cdot \mathrm{H}_{3} \mathrm{O}\right]^{+}$ & $-1148.517143^{\mathrm{e})}$ & 0.038306 & - & -25.798 & -24.925 & \\
\hline $\begin{array}{l}\mathrm{Cl}-\mathrm{Hg}-\mathrm{Cl} \\
\mathrm{H}_{3} \mathrm{O}^{+} \\
\text {Sum }\end{array}$ & $\begin{array}{r}-1071.973951 \\
-76.517394 \\
\mathbf{- 1 1 4 8 . 4 9 1 3 4 5}\end{array}$ & $\begin{array}{l}0.002146 \\
0.035287 \\
\mathbf{0 . 0 3 7} 433\end{array}$ & & & & \\
\hline
\end{tabular}

a) $\quad \Delta \mathrm{E}$ is $\mathrm{CCSD}(\mathrm{T})$ energy difference between a bound $\left[\mathrm{X}-\mathrm{Hg}-\mathrm{Y} \bullet \mathrm{H}_{3} \mathrm{O}^{+}\right]$system and individual fragments, $\mathrm{X}-\mathrm{Hg}-\mathrm{Y}$ and $\mathrm{H}_{3} \mathrm{O}^{+}$. In case of System-I: $\triangle \mathrm{E}$ is $\mathrm{CCSD}(\mathrm{T})$ energy difference between $\left[\mathrm{CH}_{3}-\mathrm{Hg}-\mathrm{OH}_{2} \bullet \mathrm{CH}_{4}\right]^{+}$and fragments $\mathrm{CH}_{3}-\mathrm{Hg}-\mathrm{CH}_{3}$ and $\mathrm{H}_{3} \mathrm{O}^{+}$.

b) $\triangle \mathrm{E}(\mathrm{ZPE})$ represents $\triangle \mathrm{E}$ with an additional correction due to $\mathrm{ZPE}$.

c) System-I: CP-corrected for Basis-set-superposition error $(\mathrm{BSSE})=1.312 \mathrm{mh}$ with respect to $\left[\mathrm{CH}_{3}-\mathrm{Hg}_{-}-\mathrm{OH}_{2}\right]^{+}$and $\mathrm{CH}_{4}$.

d) System-II: CP-corrected for Basis-set-superposition error (BSSE) $=4.056 \mathrm{mh}$.

e) System-III: CP-corrected for Basis-set-superposition error (BSSE) $=3.393 \mathrm{mh}$. 
Table SVIII. $\mathrm{H}_{5} \mathrm{O}_{2}{ }^{+}$interaction with Cl-Hg-Cl. Total energies at CCSD(T) level of theory and zero-point energies at MP2 level of theory.

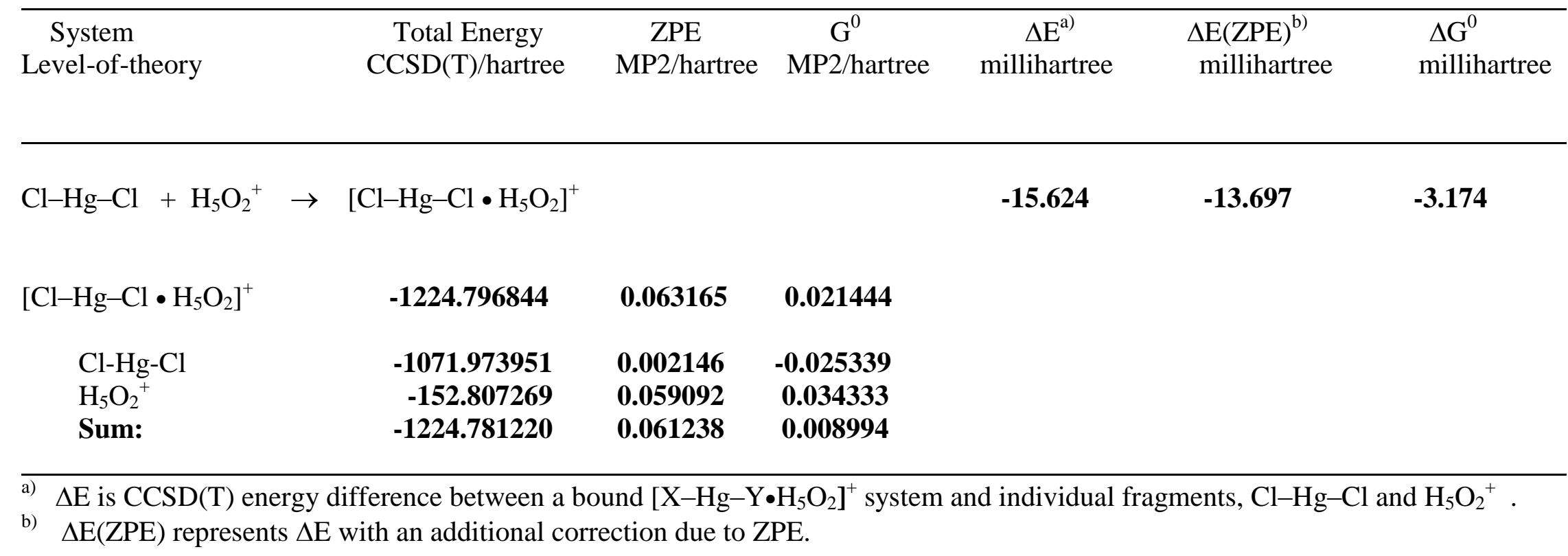


Table SIX $\left[\mathrm{CH}_{3}-\mathrm{Hg}-\mathrm{OH}_{2} \bullet \mathrm{CH}_{4}\right]^{+}$geometry optimization with counterpoise-correction.

\section{MP2-optimization:}

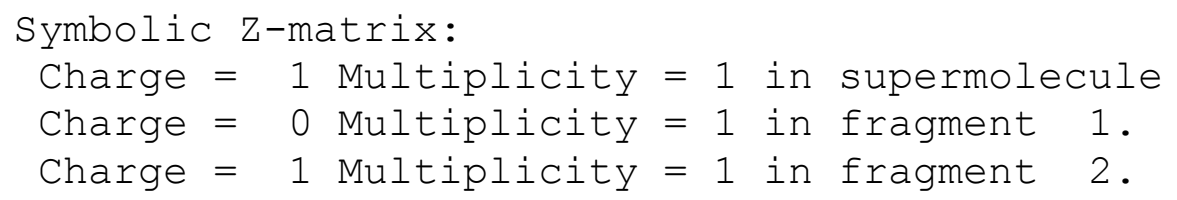

STARTING

\begin{tabular}{|c|c|c|c|}
\hline Hg (Fragment $=2$ ) & -0.44744 & -0.07157 & -0.00113 \\
\hline $\mathrm{C}($ Fragment $=1)$ & 4.11396 & 0.87291 & -0.00632 \\
\hline H $($ Fragment $=1)$ & 5.07513 & 1.37196 & 0.06143 \\
\hline H $($ Fragment $=1)$ & 4.20986 & 0.07108 & -0.73732 \\
\hline H $($ Fragment $=1)$ & 3.36951 & 1.59586 & -0.33047 \\
\hline$C($ Fragment $=2)$ & -2.2601 & 0.93097 & -0.00034 \\
\hline H (Fragment $=2)$ & -2.54015 & 1.08328 & 1.03802 \\
\hline H (Eragment $=2)$ & -2.10698 & 1.87356 & -0.51789 \\
\hline H (Fragment $=2)$ & -2.9752 & 0.30022 & -0.52067 \\
\hline$O($ Fragment $=2)$ & 1.47853 & -1.14155 & 0.04772 \\
\hline H (Fragment $=2)$ & 1.60169 & -2.05802 & -0.24027 \\
\hline $\mathrm{H}($ Fragment $=1)$ & 3.87093 & 0.48574 & 0.98203 \\
\hline H (Fragment $=2)$ & 2.33866 & -0.68933 & 0.01382 \\
\hline \multicolumn{4}{|c|}{ MP2 result } \\
\hline Counterpoise: c & d energy & \multicolumn{2}{|c|}{-308.767627465143} \\
\hline Counterpoise: & hergy = & \multicolumn{2}{|c|}{0.001224163545} \\
\hline
\end{tabular}

Rotating derivatives to standard orientation.

\begin{tabular}{|c|c|c|c|}
\hline & 1 & 2 & 3 \\
\hline & A & $\mathrm{A}$ & A \\
\hline Frequencies & 1.3486 & 7.8742 & 21.1059 \\
\hline Red. masses & 1.0288 & 1.0498 & 3.4207 \\
\hline Frc consts & 0.0000 & 0.0000 & 0.0009 \\
\hline IR Inten & 0.1071 & 0.0766 & 0.7629 \\
\hline & 4 & 5 & 6 \\
\hline & A & A & A \\
\hline Frequencies & 71.6342 & 95.2669 & 115.0029 \\
\hline Red. masses & 1.1291 & 2.7031 & 3.7041 \\
\hline Frc consts & 0.0034 & 0.0145 & 0.0289 \\
\hline IR Inten & 0.1175 & 1.1816 & 2.7644 \\
\hline & 7 & 8 & 9 \\
\hline & A & $\mathrm{A}$ & A \\
\hline Frequencies & 138.5207 & 149.5043 & 161.3586 \\
\hline Red. masses & 2.0177 & 1.4947 & 1.0318 \\
\hline
\end{tabular}




\begin{tabular}{|c|c|c|c|c|}
\hline \multirow{4}{*}{$\begin{array}{l}\text { Frc consts } \\
\text { IR Inten }\end{array}$} & -- & 0.0228 & 0.0197 & 0.0158 \\
\hline & -- & 34.7510 & 69.1961 & 7.5999 \\
\hline & & 10 & 11 & 12 \\
\hline & & A & A & A \\
\hline Frequencies & -- & 314.6155 & 364.7499 & 543.2254 \\
\hline Red. masses & -- & 1.0934 & 5.7526 & 4.7164 \\
\hline Frc consts & -- & 0.0638 & 0.4509 & 0.8200 \\
\hline \multirow[t]{3}{*}{ IR Inten } & -- & 182.0657 & 31.1515 & 0.9375 \\
\hline & & 13 & 14 & 15 \\
\hline & & A & A & A \\
\hline Frequencies & -- & 646.9352 & 884.7238 & 886.6558 \\
\hline Red. masses & -- & 1.1078 & 1.1475 & 1.1508 \\
\hline Frc consts & -- & 0.2732 & 0.5292 & 0.5331 \\
\hline \multirow[t]{3}{*}{ IR Inten } & -- & 35.5620 & 23.1034 & 29.6996 \\
\hline & & 16 & 17 & 18 \\
\hline & & A & A & A \\
\hline Frequencies & -- & 1292.3146 & 1372.1477 & 1410.2110 \\
\hline Red. masses & -- & 1.1623 & 1.1731 & 1.1773 \\
\hline Frc consts & -- & 1.1437 & 1.3014 & 1.3794 \\
\hline \multirow[t]{3}{*}{ IR Inten } & -- & 46.4470 & 24.3354 & 16.2301 \\
\hline & & 19 & 20 & 21 \\
\hline & & A & A & A \\
\hline Frequencies & -- & 1419.6683 & 1490.4616 & 1490.7089 \\
\hline Red. masses & -- & 1.1718 & 1.0600 & 1.0601 \\
\hline Frc consts & -- & 1.3915 & 1.3874 & 1.3879 \\
\hline \multirow[t]{3}{*}{ IR Inten } & -- & 17.8598 & 2.4160 & 2.2191 \\
\hline & & 22 & 23 & 24 \\
\hline & & A & A & A \\
\hline Frequencies & -- & 1618.8943 & 1621.9223 & 1670.7442 \\
\hline Red. masses & -- & 1.0135 & 1.0086 & 1.0822 \\
\hline Frc consts & -- & 1.5650 & 1.5632 & 1.7798 \\
\hline \multirow[t]{3}{*}{ IR Inten } & -- & 14.0957 & 5.1863 & 35.8161 \\
\hline & & 25 & 26 & 27 \\
\hline & & A & A & A \\
\hline Frequencies & -- & 3112.4241 & 3158.5061 & 3245.8319 \\
\hline Red. masses & -- & 1.0093 & 1.0258 & 1.1035 \\
\hline Frc consts & -- & 5.7606 & 6.0292 & 6.8496 \\
\hline \multirow[t]{3}{*}{ IR Inten } & -- & 17.4547 & 4.1817 & 14.7532 \\
\hline & & 28 & 29 & 30 \\
\hline & & A & A & A \\
\hline Frequencies & -- & 3259.7253 & 3286.3679 & 3293.4976 \\
\hline Red. masses & -- & 1.1016 & 1.1000 & 1.1081 \\
\hline Frc consts & -- & 6.8964 & 6.9998 & 7.0817 \\
\hline IR Inten & -- & 14.5748 & 2.2163 & 4.7845 \\
\hline & & 31 & 32 & 33 \\
\hline & & A & A & A \\
\hline Frequencies & -- & 3294.3066 & 3772.5523 & 3912.0090 \\
\hline
\end{tabular}




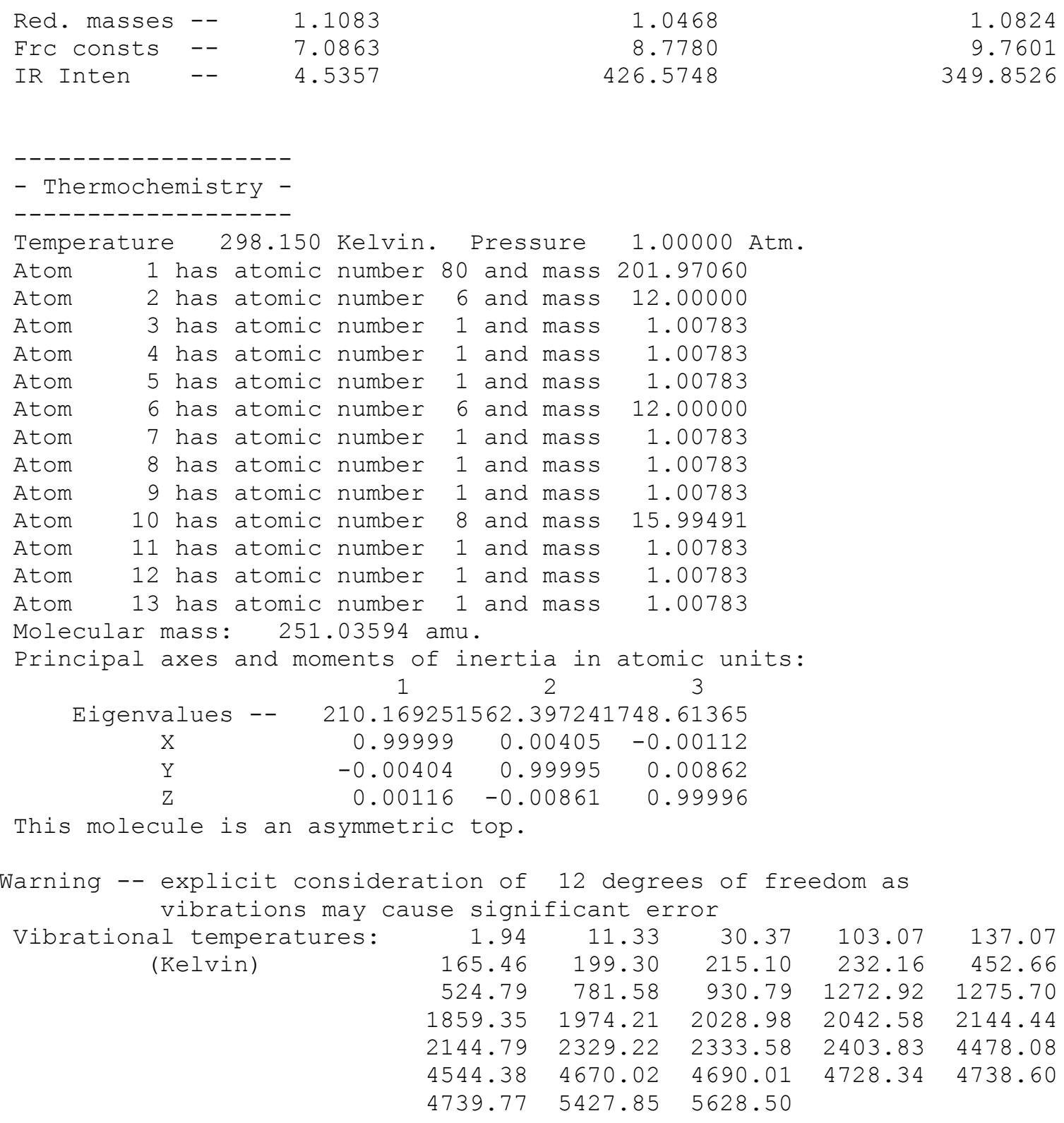

Zero-point correction=

Thermal correction to Energy=

Thermal correction to Enthalpy=

Thermal correction to Gibbs Free Energy=

Sum of electronic and zero-point Energies=

Sum of electronic and thermal Energies=

Sum of electronic and thermal Enthalpies=

Sum of electronic and thermal Free Energies=

\author{
0.109636 (Hartree/Particle) \\ 0.120649 \\ 0.121593 \\ 0.064586 \\ $-308.657991$ \\ $-308.646978$ \\ $-308.646034$ \\ $-308.703041$
}




\section{CCSD (T) Result:}

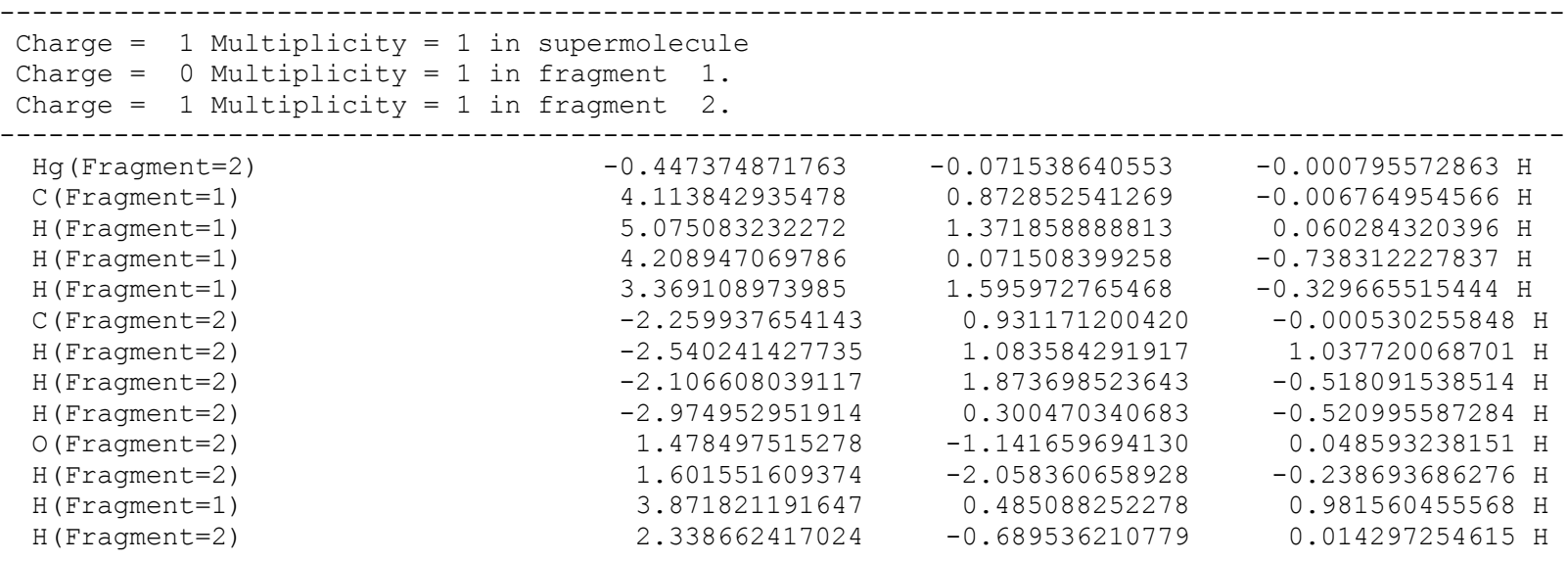

\section{CCSD (T) Result:}

Counterpoise: corrected energy $=\quad-308.832814709825$

Counterpoise: BSSE energy $=0.001311946240$ 
Table SXX. The data for MP2-geometry optimization of $\mathrm{CH}_{3}-\mathrm{Hg}-\mathrm{CH}_{3}$.

-- Stationary point found.

! (Angstroms and Degrees) !

\begin{tabular}{|c|c|c|c|c|c|}
\hline ! Name & Definition & Value & Derivati & ive Info. & ! \\
\hline ! R1 & $R(1,2)$ & 2.1045 & $-\mathrm{DE} / \mathrm{DX}=$ & 0.0 & ! \\
\hline ! R2 & $R(1,6)$ & 2.1045 & $-\mathrm{DE} / \mathrm{DX}=$ & 0.0 & ! \\
\hline ! R3 & $R(2,3)$ & 1.0897 & $-\mathrm{DE} / \mathrm{DX}=$ & 0.0 & ! \\
\hline ! R4 & $R(2,4)$ & 1.0897 & $-\mathrm{DE} / \mathrm{DX}=$ & 0.0 & ! \\
\hline ! R5 & $R(2,5)$ & 1.0897 & $-\mathrm{DE} / \mathrm{DX}=$ & 0.0 & ! \\
\hline ! R6 & $R(6,7)$ & 1.0897 & $-\mathrm{DE} / \mathrm{DX}=$ & 0.0 & ! \\
\hline ! R7 & $R(6,8)$ & 1.0897 & $-\mathrm{DE} / \mathrm{DX}=$ & 0.0 & ! \\
\hline ! R8 & $R(6,9)$ & 1.0897 & $-\mathrm{DE} / \mathrm{DX}=$ & 0.0 & ! \\
\hline ! A1 & $A(1,2,3)$ & 110.6778 & $-\mathrm{DE} / \mathrm{DX}=$ & 0.0 & ! \\
\hline ! A2 & $A(1,2,4)$ & 110.6778 & $-\mathrm{DE} / \mathrm{DX}=$ & 0.0 & ! \\
\hline ! A3 & $A(1,2,5)$ & 110.6778 & $-\mathrm{DE} / \mathrm{DX}=$ & 0.0 & ! \\
\hline ! A4 & $A(3,2,4)$ & 108.2382 & $-\mathrm{DE} / \mathrm{DX}=$ & 0.0 & ! \\
\hline ! A5 & $A(3,2,5)$ & 108.2382 & $-\mathrm{DE} / \mathrm{DX}=$ & 0.0 & ! \\
\hline ! A6 & $A(4,2,5)$ & 108.2382 & $-\mathrm{DE} / \mathrm{DX}=$ & 0.0 & ! \\
\hline ! A7 & $A(1,6,7)$ & 110.6778 & $-\mathrm{DE} / \mathrm{DX}=$ & 0.0 & ! \\
\hline ! A8 & $A(1,6,8)$ & 110.6778 & $-\mathrm{DE} / \mathrm{DX}=$ & 0.0 & ! \\
\hline ! A9 & $A(1,6,9)$ & 110.6778 & $-\mathrm{DE} / \mathrm{DX}=$ & 0.0 & ! \\
\hline ! A10 & $A(7,6,8)$ & 108.2382 & $-\mathrm{DE} / \mathrm{DX}=$ & 0.0 & ! \\
\hline ! A11 & $A(7,6,9)$ & 108.2382 & $-\mathrm{DE} / \mathrm{DX}=$ & 0.0 & ! \\
\hline ! A12 & $A(8,6,9)$ & 108.2382 & $-\mathrm{DE} / \mathrm{DX}=$ & 0.0 & ! \\
\hline ! A13 & $\mathrm{L}(2,1,6,4,-1)$ & 180.0 & $-\mathrm{DE} / \mathrm{DX}=$ & 0.0 & ! \\
\hline ! A14 & $\mathrm{L}(2,1,6,4,-2)$ & 180.0 & $-\mathrm{DE} / \mathrm{DX}=$ & 0.0 & ! \\
\hline ! D1 & $D(3,2,6,7)$ & 120.0063 & $-\mathrm{DE} / \mathrm{DX}=$ & 0.0 & ! \\
\hline ! D2 & $\mathrm{D}(3,2,6,8)$ & -119.9937 & $-\mathrm{DE} / \mathrm{DX}=$ & 0.0 & ! \\
\hline ! D3 & $\mathrm{D}(3,2,6,9)$ & 0.0063 & $-\mathrm{DE} / \mathrm{DX}=$ & 0.0 & ! \\
\hline ! D4 & $\mathrm{D}(4,2,6,7)$ & -119.9937 & $-\mathrm{DE} / \mathrm{DX}=$ & 0.0 & ! \\
\hline ! D5 & $\mathrm{D}(4,2,6,8)$ & 0.0063 & $-\mathrm{DE} / \mathrm{DX}=$ & 0.0 & ! \\
\hline ! D6 & $\mathrm{D}(4,2,6,9)$ & 120.0063 & $-\mathrm{DE} / \mathrm{DX}=$ & 0.0 & ! \\
\hline ! D7 & $\mathrm{D}(5,2,6,7)$ & 0.0063 & $-\mathrm{DE} / \mathrm{DX}=$ & 0.0 & ! \\
\hline ! D8 & $D(5,2,6,8)$ & 120.0063 & $-\mathrm{DE} / \mathrm{DX}=$ & 0.0 & ! \\
\hline ! D9 & $D(5,2,6,9)$ & -119.9937 & $-\mathrm{DE} / \mathrm{DX}=$ & 0.0 & ! \\
\hline
\end{tabular}

GradGradGradGradGradGradGradGradGradGradGradGradGradGradGradGradGradGrad

$$
\begin{gathered}
\mathrm{E} 2=-0.4602618546 \mathrm{D}+00 \mathrm{EUMP} 2=-0.23217016021166 \mathrm{D}+03 \\
\text { The electronic state is 1-A1. }
\end{gathered}
$$

Harmonic frequencies ( $\mathrm{cm} * \star-1)$, IR intensities (KM/Mole), Raman scattering activities ( $A^{* \star 4 / A M U), ~ d e p o l a r i z a t i o n ~ r a t i o s ~ f o r ~ p l a n e ~ a n d ~ u n p o l a r i z e d ~}$ incident light, reduced masses (AMU), force constants (mDyne/A),

\begin{tabular}{|c|c|c|c|c|}
\hline & & 1 & 2 & 3 \\
\hline & & A1 & $\mathrm{E}$ & $\mathrm{E}$ \\
\hline Frequencies & -- & 42.6016 & 145.1571 & 145.1571 \\
\hline Red. masses & -- & 1.0078 & 2.7828 & 2.7828 \\
\hline Frc consts & -- & 0.0011 & 0.0345 & 0.0345 \\
\hline IR Inten & -- & 0.0000 & 0.0449 & 0.0449 \\
\hline & & 4 & 5 & 6 \\
\hline & & A1 & A2 & $E$ \\
\hline Frequencies & -- & 527.3465 & 552.0616 & 726.3182 \\
\hline Red. masses & -- & 3.9904 & 4.0984 & 1.1443 \\
\hline Frc consts & -- & 0.6538 & 0.7359 & 0.3557 \\
\hline IR Inten & -- & 0.0000 & 44.5414 & 0.0000 \\
\hline
\end{tabular}
and normal coordinates: 


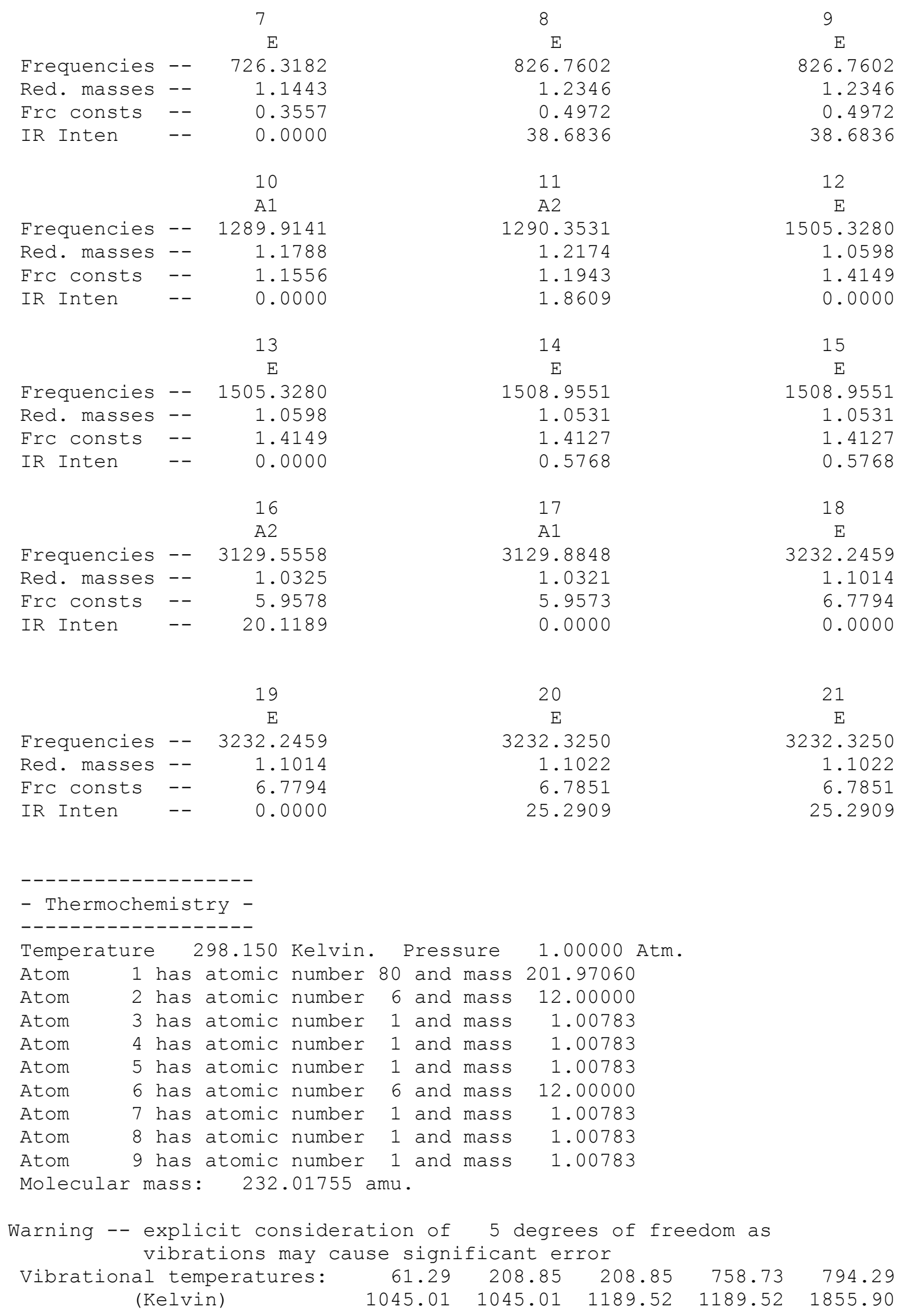




$\begin{array}{lllll}1856.53 & 2165.83 & 2165.83 & 2171.05 & 2171.05 \\ 4502.73 & 4503.20 & 4650.48 & 4650.48 & 4650.59\end{array}$

Zero-point correction=

0.073621 (Hartree/Particle)

Thermal correction to Energy=

0.079390

Thermal correction to Enthalpy=

0.080334

Thermal correction to Gibbs Free Energy=

0.044808

Sum of electronic and zero-point Energies=

$-232.096539$

Sum of electronic and thermal Energies=

Sum of electronic and thermal Enthalpies=

$-232.090770$

Sum of electronic and thermal Free Energies=

$-232.089826$

$-232.125352$

\footnotetext{
\# P CCSD-T (FC, MaxCyC=100) SCF (Tight) CHKbasis GEOM=allcheck 
Table SXXI. The data for MP2-geometry optimization of $\mathrm{CH}_{3}-\mathrm{Hg}^{+}$.

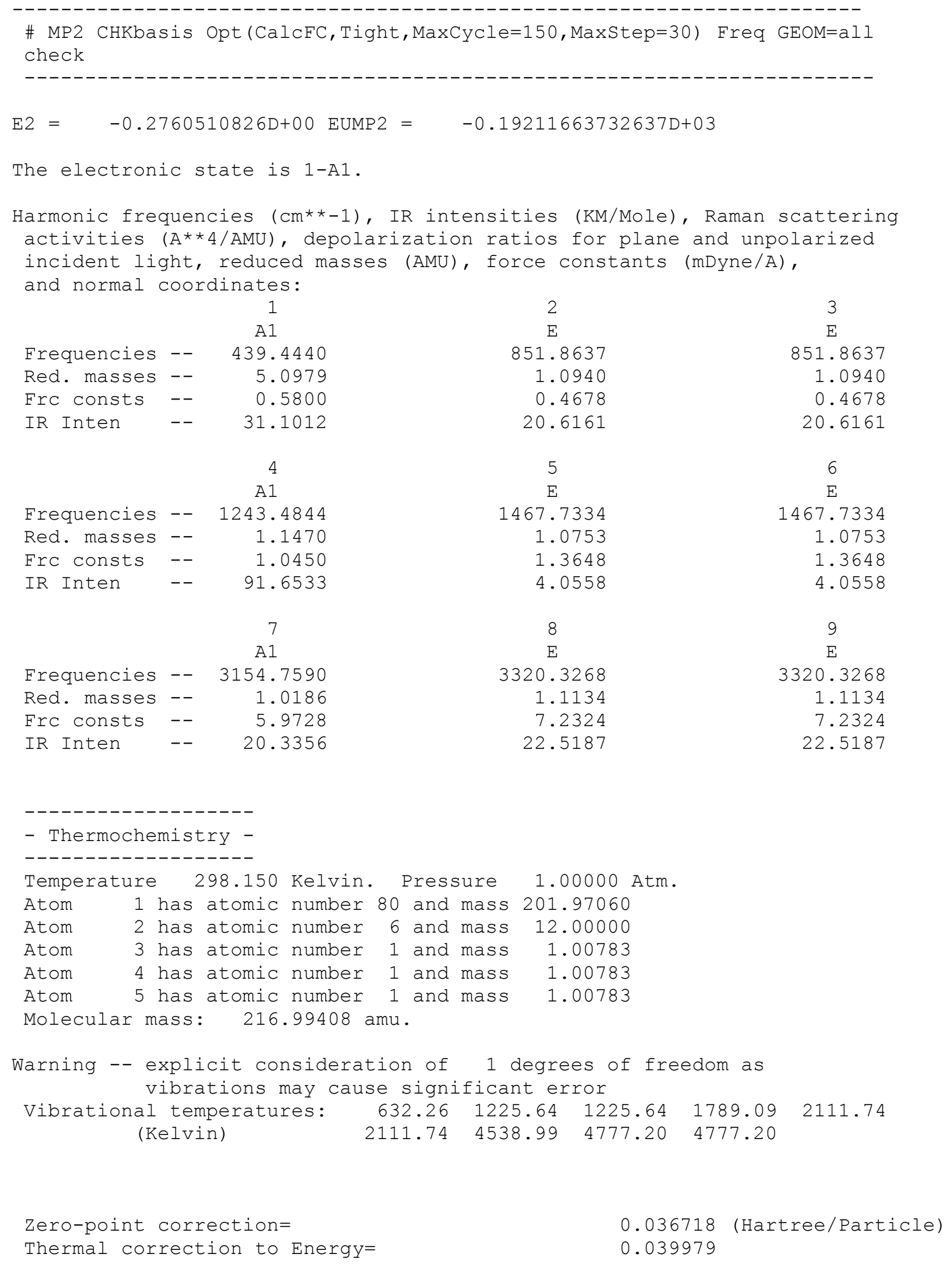


Thermal correction to Enthalpy=

Thermal correction to Gibbs Free Energy=

Sum of electronic and zero-point Energies=

Sum of electronic and thermal Energies=

Sum of electronic and thermal Enthalpies=

Sum of electronic and thermal Free Energies=
0.040923

0.011323

$-192.079919$

$-192.076659$

$-192.075715$

$-192.105315$

$==\mathrm{=}=\mathrm{=}=\mathrm{=}=\mathrm{=}=\mathrm{=}=\mathrm{=}=\mathrm{=}=\mathrm{=}=\mathrm{=}=\mathrm{=}=\mathrm{=}=\mathrm{=}=\mathrm{=}=\mathrm{=}=\mathrm{=}=\mathrm{=}=\mathrm{=}=\mathrm{=}=\mathrm{=}=\mathrm{=}=\mathrm{=}=\mathrm{=}=\mathrm{=}=\mathrm{=}$

\# P CCSD-T (FC, MaxCyc=100) SCF(Tight) CHKbasis GEOM=allcheck

$$
\operatorname{CCSD}(T)=-0.19214863861 \mathrm{D}+03
$$

$\backslash$ St

ate $=1-\mathrm{A} 1 \backslash \mathrm{HF}=-191.8405862 \backslash \mathrm{MP} 2=-192.1166373 \backslash \mathrm{MP} 3=-192.130343 \backslash \mathrm{MP} 4 \mathrm{D}=-192.13$ $81961 \backslash \mathrm{MP} 4 \mathrm{DQ}=-192.135011 \backslash \mathrm{MP} 4 \mathrm{SDQ}=-192.1398528 \backslash \mathrm{CCSD}=-192.1388403 \backslash \mathrm{CCSD}(\mathrm{T})=$ $-192.1486386$

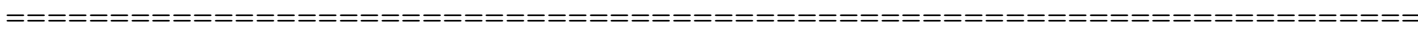


Table SXXII. The data for the MP2-optimization of the complex $\left[\mathrm{CH}_{3}-\mathrm{Hg}-\mathrm{CH}_{3} \bullet \mathrm{OH}\right]^{-}(\mathrm{CP}$-corrected energy).

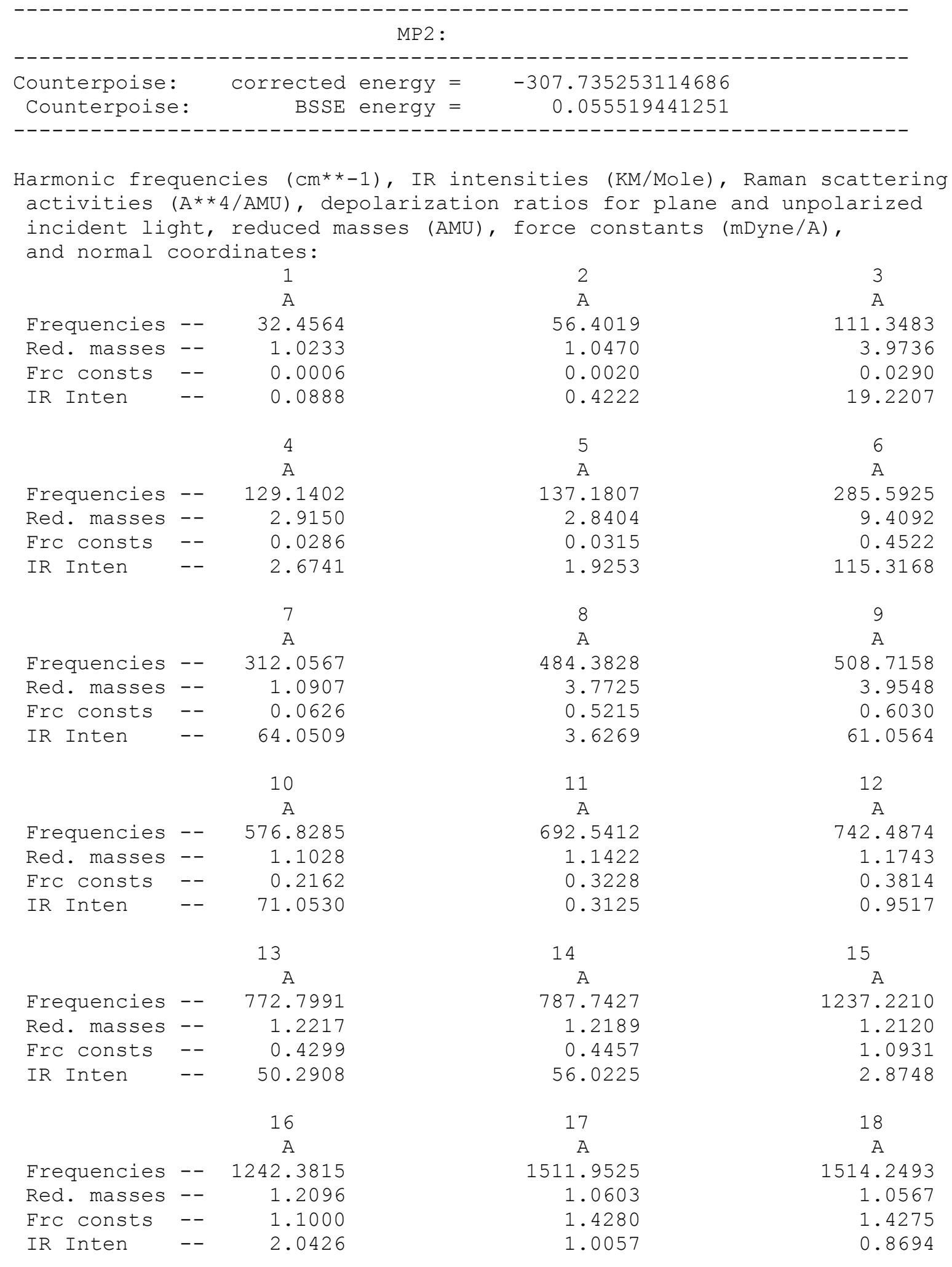




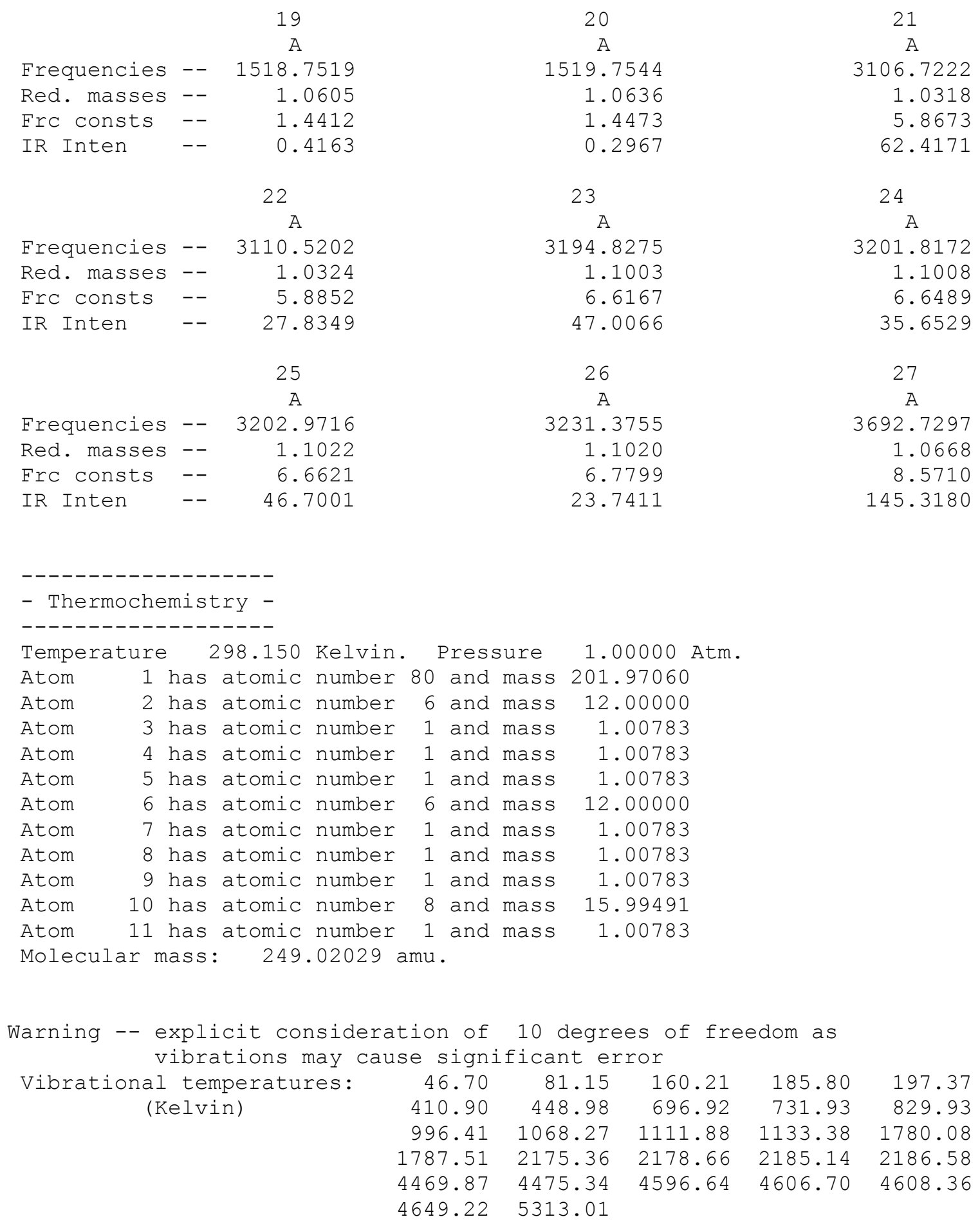

Zero-point correction=

Thermal correction to Energy=

Thermal correction to Enthalpy=

Thermal correction to Gibbs Free Energy=

Sum of electronic and zero-point Energies=

Sum of electronic and thermal Energies=

Sum of electronic and thermal Enthalpies=

Sum of electronic and thermal Free Energies=

\author{
0.084098 (Hartree/Particle) \\ 0.092583 \\ 0.093527 \\ 0.048759 \\ $-307.651155$ \\ $-307.642670$ \\ $-307.641726$ \\ $-307.686494$
}


Table SXXIII. Pseudopotential (MDF60) parameters used in the present study for Hg.

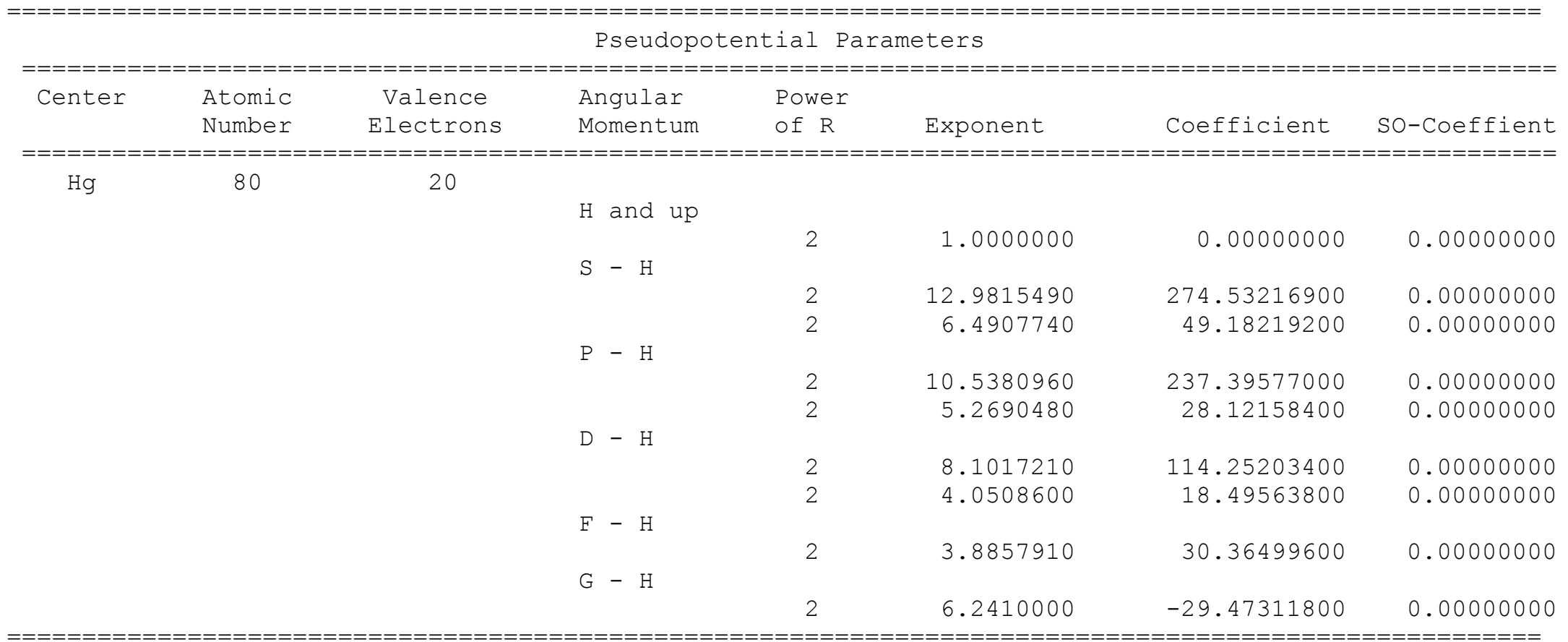



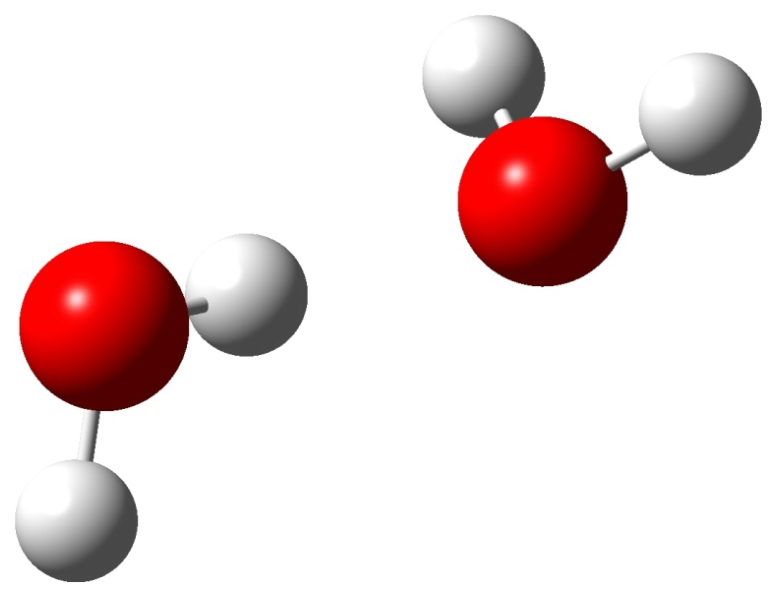

(A) $\mathrm{H}_{2} \mathrm{O} \bullet \mathrm{H}_{2} \mathrm{O}$
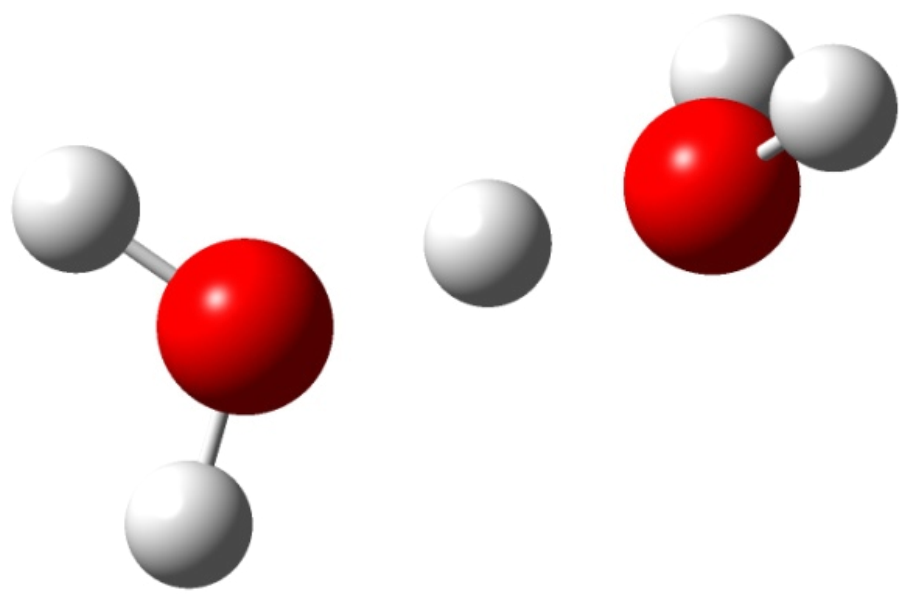

(B) $\mathbf{H}_{5} \mathrm{O}_{2}^{+}$

Figure S1. Optimized geometries for water dimer (panel A) and Zundel ion $\mathrm{H}_{5} \mathrm{O}_{2}{ }^{+}$(panel B). 


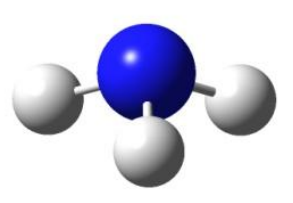

(A) $\mathbf{N H}_{3}$

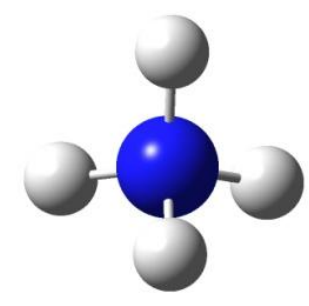

(B) $\mathbf{N H}_{4}{ }^{+}$

Figure S2. Optimized structures for $\mathrm{NH}_{3}$ (panel A) and $\mathrm{NH}_{4}{ }^{+}$(panel B). 


\section{'○”}

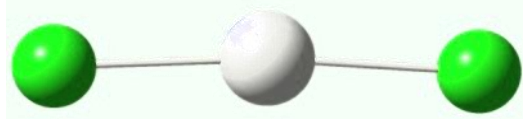

(A) $\mathrm{Cl}-\mathrm{Hg}-\mathrm{Cl} \bullet \mathrm{H}_{2} \mathrm{O}$
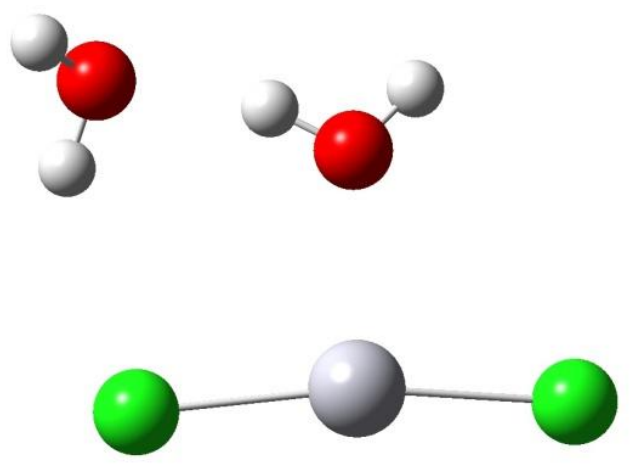

\section{(B) $\mathrm{Cl}-\mathrm{Hg}-\mathrm{Cl} \bullet\left(\mathrm{H}_{2} \mathrm{O}-\mathrm{H}_{2} \mathrm{O}\right)$}

Figure S3. Comparison of the bound complexes resulting from the interaction of $\mathrm{Cl}-\mathrm{Hg}-\mathrm{Cl}$ with $\mathrm{H}_{2} \mathrm{O}$ (panel A) and $\mathrm{H}_{2} \mathrm{O}-\mathrm{OH}_{2}$ (panel B). 